University of South Florida

DIGITAL COMMONS

Digital Commons @ University of

@ UNIVERSITY OF SOUTH FLORIDA

South Florida

$1-1-2013$

\title{
2013 Accountability Report USF Tampa
}

USF

Follow this and additional works at: https://digitalcommons.usf.edu/usf_accountability_reports

\section{Scholar Commons Citation}

USF, "2013 Accountability Report USF Tampa" (2013). USF Accountability Reports. 37.

https://digitalcommons.usf.edu/usf_accountability_reports/37

This Article is brought to you for free and open access by the USF Archives at Digital Commons @ University of South Florida. It has been accepted for inclusion in USF Accountability Reports by an authorized administrator of Digital Commons @ University of South Florida. For more information, please contact digitalcommons@usf.edu. 


\section{2-13 \\ Annual Accountability Report}

\section{UNIVERSITY OF SOUTH FLORIDA TAMPA}

STATE UNIVERSITY SYSTEM of FLORIDA Board of Governors 


\section{$\underline{\text { TABLE OF CONTENTS }}$}

\section{EXECUTIVE SUMMARY}

DASHBOARD

p. 2

KEY ACHIEVEMENTS

p. 5

NARRATIVE

p. 6

\section{DATA TABLES}

SECTION 1. FINANCIAL RESOURCES p. 14

SECTION 2. PERSONNEL p. 18

SECTION 3. ENROLLMENT p. 19

SECTION 4. UNDERGRADUATE EDUCATION p. 21

SECTION 5. GRADUATE EDUCATION p. 30

SECTION 6. RESEARCH \& ECONOMIC DEVELOPMENT p. 33 


\section{Dashboard}

\begin{tabular}{|c|c|c|c|c|c|c|c|c|}
\hline $\begin{array}{l}\text { Headcount } \\
\text { Enrollments }\end{array}$ & $\begin{array}{l}\text { Fall } \\
2012\end{array}$ & $\begin{array}{c}\% \\
\text { Total }\end{array}$ & $\begin{array}{l}2007-2012 \\
\% \text { Change }\end{array}$ & \multicolumn{3}{|c|}{ Degree Programs Offered } & \multicolumn{2}{|c|}{2012 Carnegie Classifications } \\
\hline TOTAL & 41,212 & $100 \%$ & $6 \%$ & \multicolumn{2}{|c|}{ TOTAL (as of Spring 2013) } & 230 & \multirow{2}{*}{ Basic: } & \multirow{2}{*}{$\begin{array}{l}\text { Research Universities } \\
\text { (very high research activity) }\end{array}$} \\
\hline White & 23,552 & $57 \%$ & $-4 \%$ & \multicolumn{2}{|l|}{ Baccalaureate } & 83 & & \\
\hline Hispanic & 6,834 & $17 \%$ & $39 \%$ & \multicolumn{2}{|l|}{ Master's } & 103 & \multirow{2}{*}{$\begin{array}{l}\text { Undergraduate } \\
\text { Instructional Program: }\end{array}$} & \multirow{2}{*}{$\begin{array}{l}\text { Balanced arts \& sciences, } \\
\text { professions, high graduate }\end{array}$} \\
\hline Black & 6,426 & $16 \%$ & $34 \%$ & \multicolumn{2}{|l|}{ Research Doctorate } & 40 & & \\
\hline Other & 4,400 & $11 \%$ & $-5 \%$ & \multicolumn{2}{|c|}{ Professional Doctorate } & 4 & \multirow{2}{*}{$\begin{array}{l}\text { Graduate } \\
\text { Instructional Program: }\end{array}$} & \multirow{2}{*}{$\begin{array}{l}\text { Comprehensive doctoral } \\
\text { with medical/veterinary }\end{array}$} \\
\hline Full-Time & 29,324 & $71 \%$ & $14 \%$ & \multirow{2}{*}{$\begin{array}{c}\text { Faculty } \\
\text { (Fall 2012) }\end{array}$} & \multirow{2}{*}{$\begin{array}{l}\text { Full- } \\
\text { Time }\end{array}$} & \multirow{2}{*}{$\begin{array}{l}\text { Part- } \\
\text { Time }\end{array}$} & & \\
\hline Part-Time & 11,888 & $29 \%$ & $-9 \%$ & & & & \multirow{2}{*}{ Size and Setting: } & \multirow{2}{*}{$\begin{array}{l}\text { Large four-year, primarily } \\
\text { nonresidential }\end{array}$} \\
\hline Undergraduate & 30,432 & $74 \%$ & $4 \%$ & TOTAL & 1,459 & 600 & & \\
\hline Graduate & 9,125 & $22 \%$ & $15 \%$ & Tenure \& Ten. Track & 990 & 74 & \multirow{2}{*}{$\begin{array}{l}\text { Community } \\
\text { Engagement: }\end{array}$} & \multirow{2}{*}{$\begin{array}{l}\text { Curricular Engagement and } \\
\text { Outreach and Partnerships }\end{array}$} \\
\hline Unclassified & 1,655 & $4 \%$ & $-11 \%$ & Non-Tenured Faculty & 469 & 526 & & \\
\hline
\end{tabular}

\section{DEGREE PRODUCTIVITY AND PROGRAM EFFICIENCY}
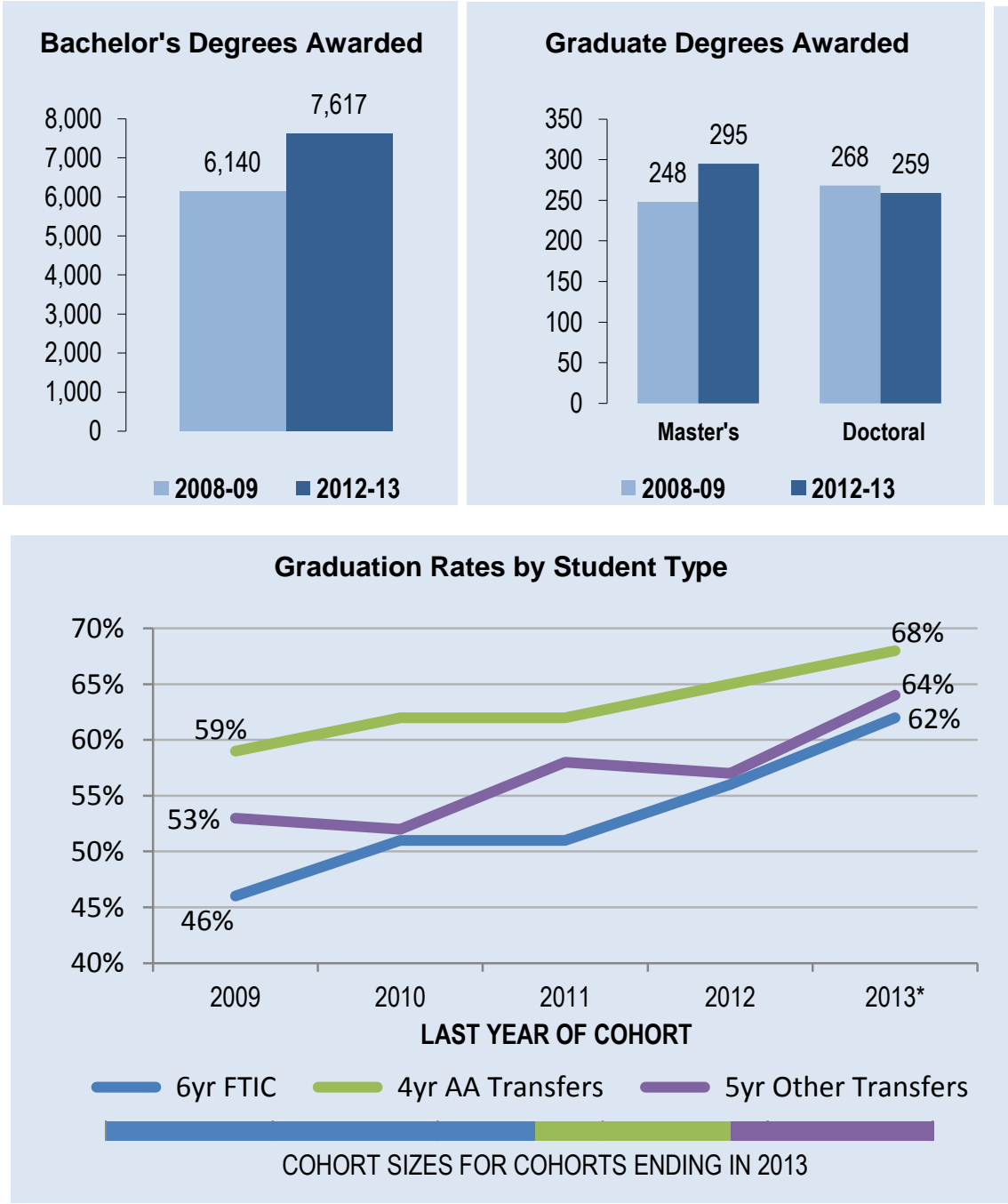

* Based on 2013 preliminary data

\section{Bachelor's Degrees by Group}

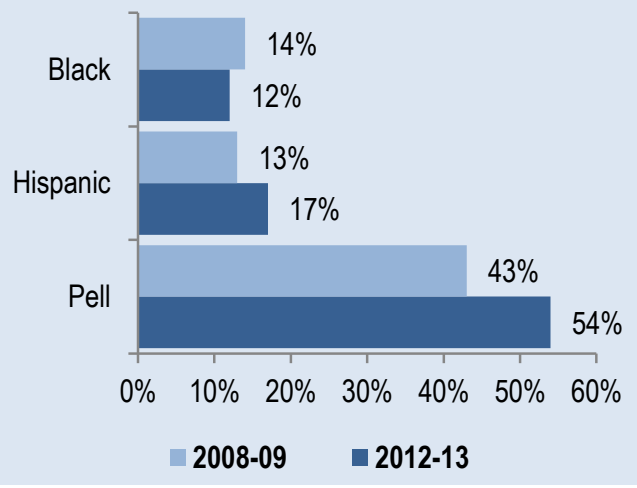

2012-13 Bachelor's Degrees Without Excess Hours

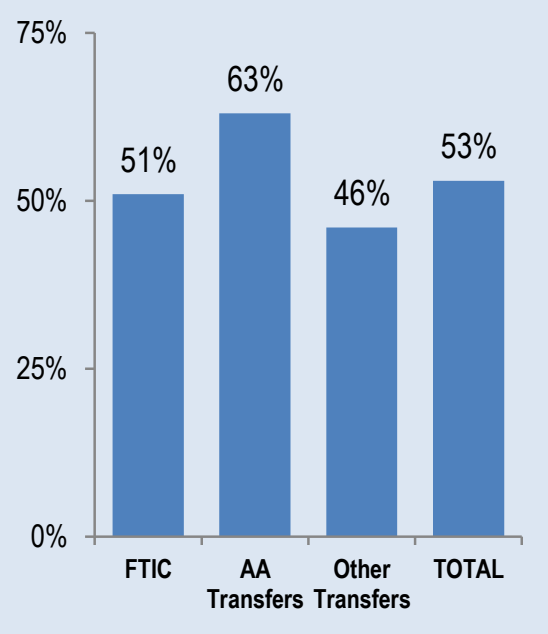




\section{Dashboard}

\section{DEGREES AWARDED IN PROGRAMS OF STRATEGIC EMPHASIS}
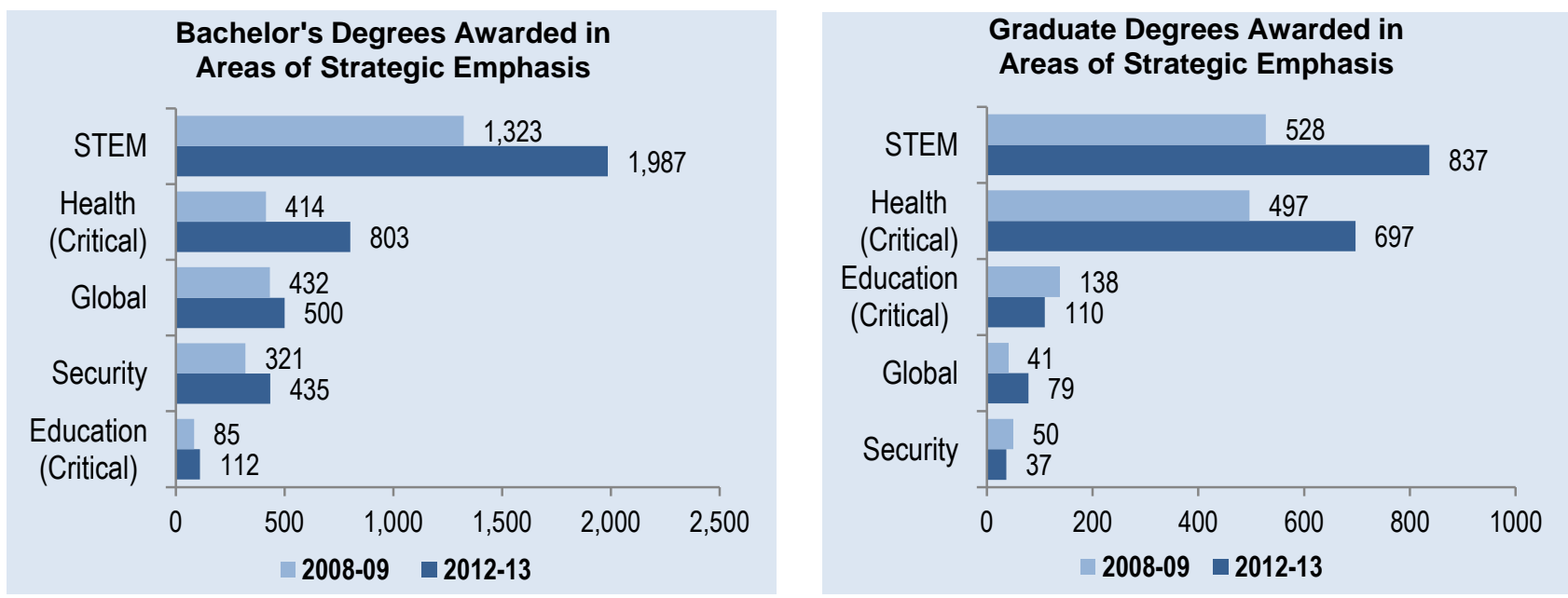

\section{RESEARCH AND COMMERCIALIZATION ACTIVITY}
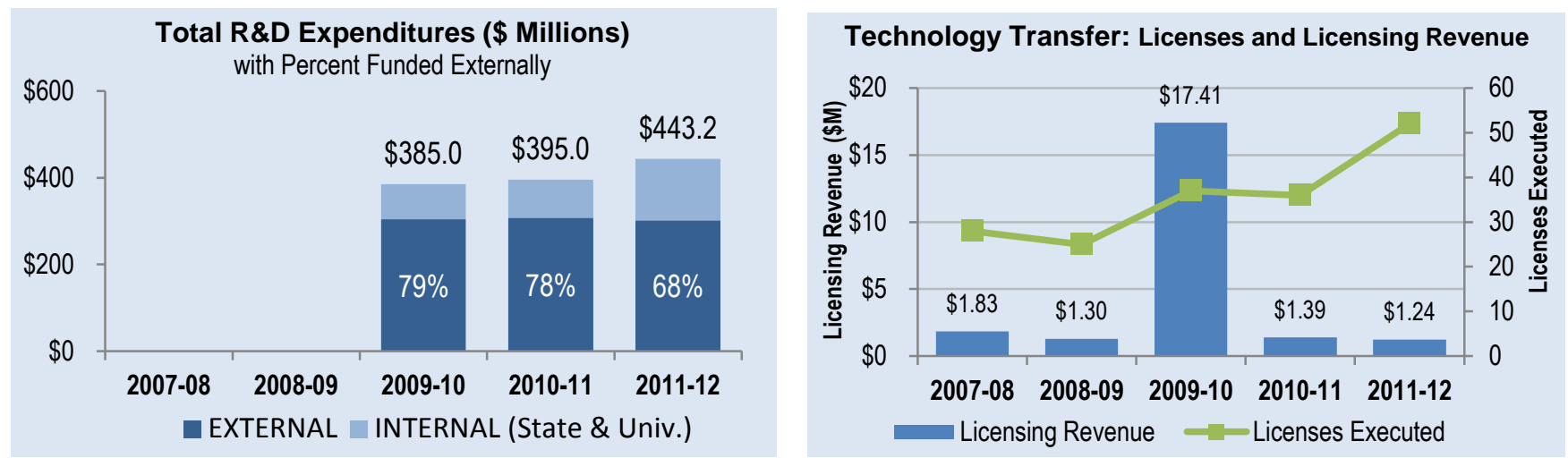

\section{RESOURCES}

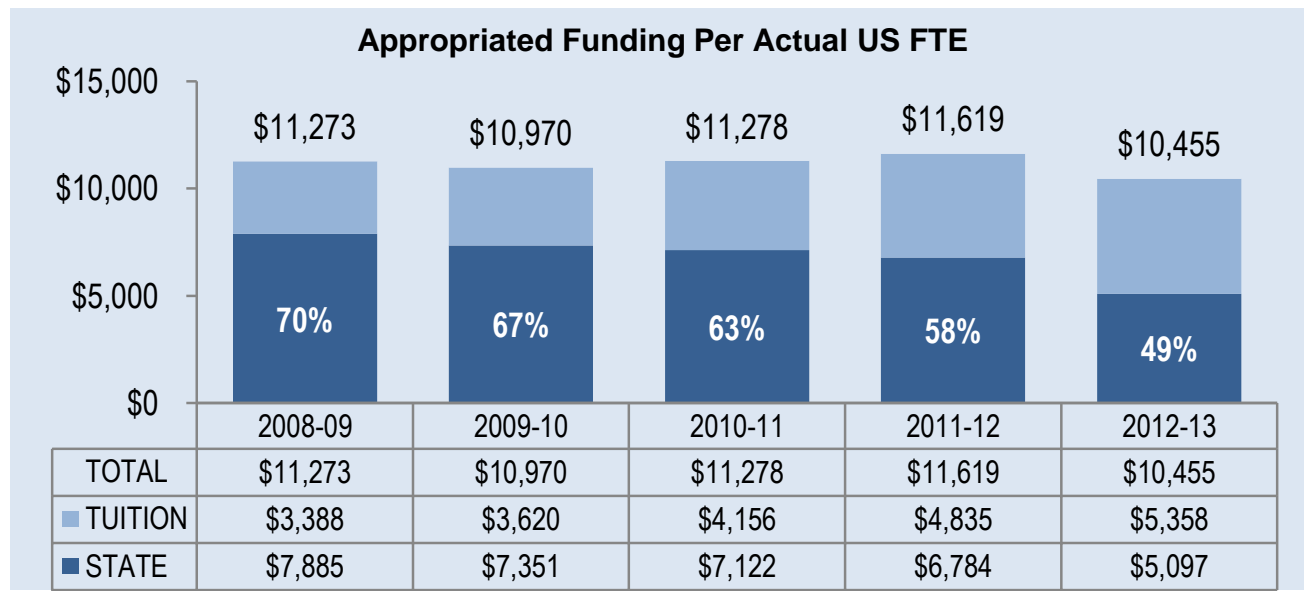

Note: Tuition is the appropriated budget authority, not the amount actually collected. This tuition data does not include noninstructional local fees. State includes General Revenues, Lottery and Other Trust funds (i.e., Federal Stimulus for 2009-10 and 2010-11 only). State funded financial aid programs that follow the student are included in tuition data. Student FTE are actual (not funded) and based on the national definition. 


\section{Dashboard}

\section{POST-GRADUATION METRICS}

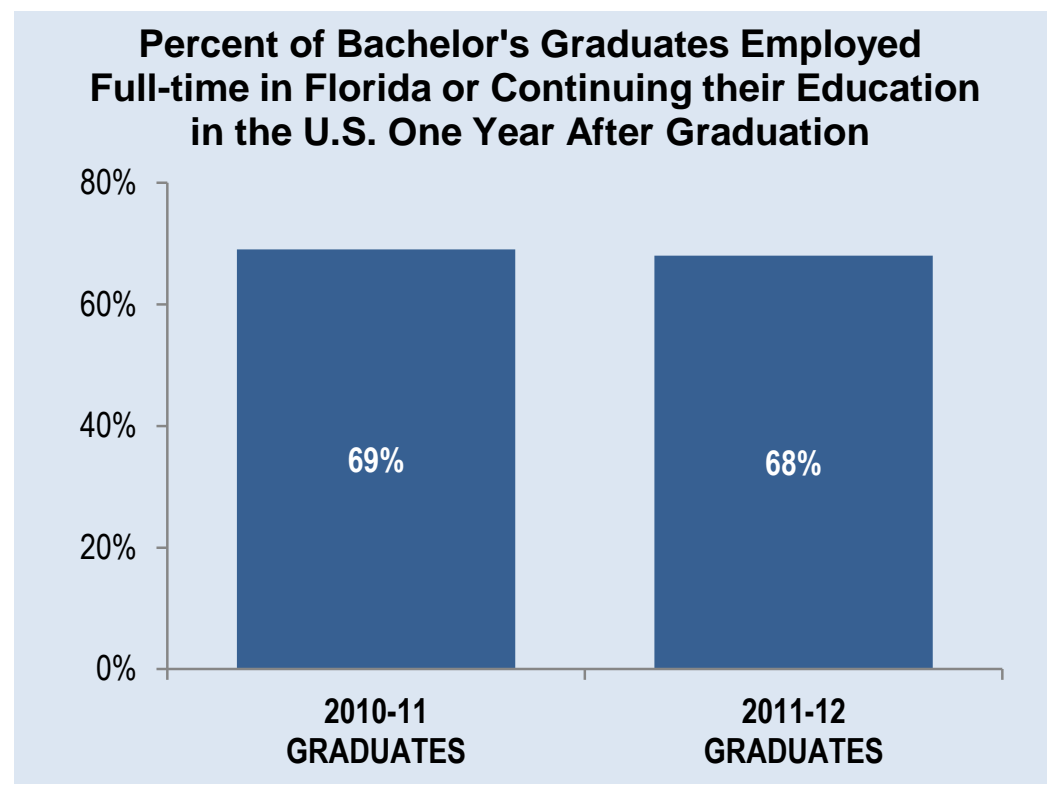

\section{Wages of Full-time Employed in Florida Baccalaureates One Year After Graduation 25th, 50th and 75th Percentiles}

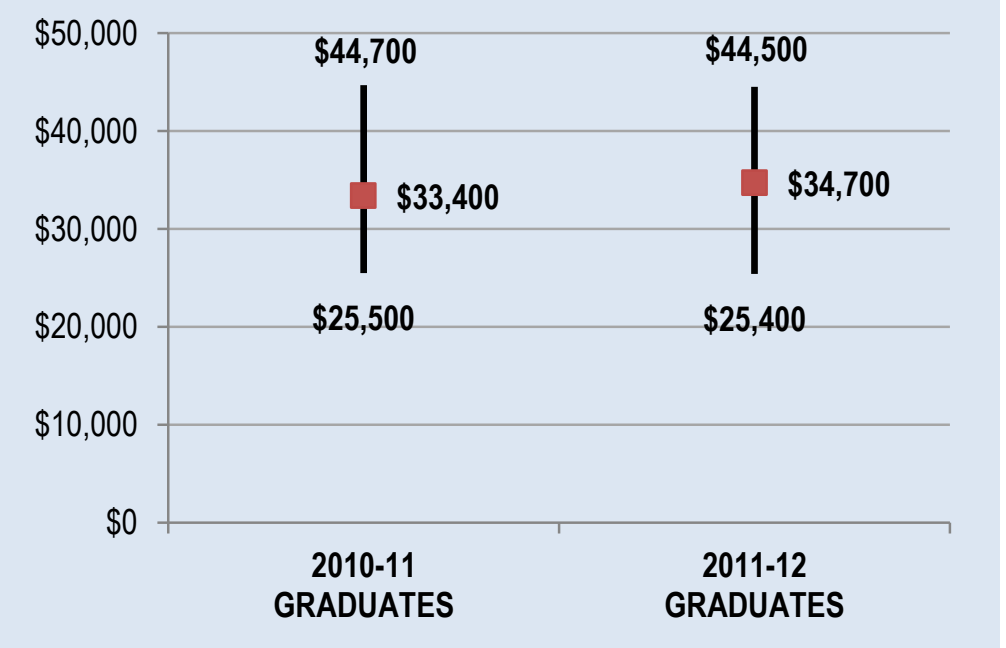

Notes: Percentages are based on the number of recent baccalaureate graduates who are either employed full-time in Florida (based on FETPIP data) or continuing their education in the U.S. (based on the National Student Clearinghouse data). Full-time employment is based on those who earned more than a full-time (40hrs a week) worker making minimum wage. Due to limitations in the data, the continuing enrollment data includes any enrollment the following year regardless of whether the enrollment was post-baccalaureate or not. These data account for $92 \%$ and $88 \%$ of the total graduating class for 2010-11 and 2011-12, respectively. BOG staff are actively working on adding non-Florida employment data to this measure for future reports.

Notes: Wage data is based on Florida's annualized Unemployment Insurance (UI) wage data for those graduates who earned more than a full-time employee making minimum wage in the fiscal quarter a full year after graduation. This wage data excludes graduates who were enrolled, regardless of their earnings. This UI wage data does not include individuals who are self-employed, employed out of state, employed by the military or federal government, or those without a valid social security number. These data account for $52 \%$ and $50 \%$ of the total graduating class for 2010-11 and 2011-12, respectively. Wages rounded to nearest hundreds. 


\section{Key Achievements (2012-2013)}

\section{STUDENT AWARDS/ACHIEVEMENTS}

1. USF is a top producer of Fulbright Scholars, with the largest total among 50 universities in 32 states coming from USF in 2013.

2. A USF first was secured this year by Christie Campla-named a National Institutes of Health Oxford-Cambridge Scholar. Campla, who specializes in cellular and molecular biology, will focus on improving methods for drug preservation and delivery.

3. USF celebrated three Tillman Military Scholars: Richard Mendez served in Iraq and Afghanistan as an Army Ranger; Anthony DeSantis served as a U.S. Marine Corps captain in Iraq; Alicia Irvin served as an Army Military Police platoon leader in Iraq. All are studying medicine.

\section{FACULTY AWARDS/ACHIEVEMENTS}

1. Autar Kaw, a USF mechanical engineering professor, was named a 2012 U.S. Professor of the Year by the Carnegie Foundation for the Advancement of Teaching. Kaw was one of four recipients of the award that is considered the nation's highest honor for undergraduate teaching.

2. Fifteen USF faculty members were named American Association for the Advancement of Science (AAAS) fellows, the fourth most fellows of any organization in 2012.

3. Two USF faculty members earned Alfred P. Sloan Foundation research fellowships. Cameron Ainsworth is a member of the USF College of Marine Science team studying the Deepwater Horizon oil spill. Jiangfeng Zhou's physics research focuses on light-generating structures.

\section{PROGRAM AWARDS/ACHIEVEMENTS}

1. USF World received one of only five Sen. Paul Simon Awards for Comprehensive Internationalization, presented by the National Association of International Educators.

2. The USF graduate entrepreneurship program was named one of the top entrepreneurship programs in the nation by The Princeton Review and Entrepreneur magazine.

3. USF's industrial/organizational psychology program was ranked first among its peers for research productivity, according to an Auburn University study.

\section{RESEARCH AWARDS/ACHIEVEMENTS}

1. Two USF inventions were selected to be featured at the first ever National Innovation Expo at the U.S. Patent and Trademark Office. The Rolling Dance Chair and SkateCase are just two of USF's hundreds of licensed technologies, which make USF the No. 1 patent-producer in the State University System.

2. Following a nine-year study, USF researchers identified a gene linked to age-related hearing loss, which could aid tens of millions of Americans who suffer from the ailment.

3. The USF-housed Florida Institute of Oceanography and U.S. Coast Guard $7^{\text {th }}$ District forged an alliance to better engage the marine science research community on disaster responses following the Deepwater Horizon oil spill.

\section{INSTITUTIONAL AWARDS/ACHIEVEMENTS}

1. USF's graduation rate continued to climb, reaching a record-high 63 percent in 2013 . That's a sixpercentage point increase in just one year.

2. The university ranked among the country's "best values" in public higher education by Kiplinger's Personal Finance magazine, coming in at No. 57 nationwide.

3. USF surpassed its $\$ 600$ million goal for the USF: Unstoppable campaign, raising more than $\$ 75$ million for student scholarships, \$34 million for faculty chairs and more than $\$ 300$ million to support academic program enhancements. 


\section{Narrative}

\section{STRENGTHEN QUALITY AND REPUTATION OF ACADEMIC PROGRAMS AND UNIVERSITIES}

At USF, student success is rightly placed at the center of the university's mission, as a permanent institutional priority. That focus has paid off.

In 2012, USF's graduation rate for the 2006 cohort climbed to a record 57 percent, reflecting the thirdhighest growth rate of all research institutions in the nation. Then in 2013, that rate jumped to 63 percent for the 2007 cohort. In just a year, USF's graduation rate jumped a full six percentage points-a result of a myriad of new USF initiatives designed to ensure that students maximize their time at USF. These include a strengthened advising system, new audit degree and automated course tracking systems, redesigned gatekeeper courses, expanded on-campus employment opportunities, new living and learning communities, an expansion of a Learning Commons in the library and a revolutionary new Science, Math, and Research Technology (SMART) Lab, which offers a new active-learning approach to critical mathematics courses.

On the front end, USF's admissions standards are higher than ever. The students who enrolled at USF in fall 2012, the Class of 2016, had average SAT scores of 1209 and high school GPAs of 3.94, the highest in USF's history. USF is dedicated to ensuring each of these students graduates on time with a degree that will lead to a productive career.

While they are at USF, they will benefit from high-quality academic programs led by nationally recognized faculty. One standout is Dr. Autar Kaw, a USF mechanical engineering professor who was named a 2012 U.S. Professor of the Year by the Carnegie Foundation for the Advancement of Teaching and Council for Advancement and Support of Education (CASE). This is considered the highest honor for an undergraduate educator.

Meanwhile, USF students are also being nationally and internationally recognized for their accomplishments. In just two years, USF students have been awarded nearly 100 competitive national awards - the most among the entire State University System. Recipients of these awards are students with the strongest combination of academic achievements, extracurricular accomplishments, and potential for success in rigorous academic studies. Typically, winners represent less than one percent of applicants.

Many USF graduate level programs continue to be ranked among the best according to the 2014 U.S. News and World Report Graduate School Rankings. Newly ranked USF graduate programs in the top 50 include Industrial and Organizational Psychology (No. 4), Public Health (No. 21), Library and Information Studies (No. 24), and Industrial/Manufacturing Engineering (No. 42). Previously ranked USF graduate programs that continue to hold a ranking in the top 50 include Audiology (No. 12), Criminology (No. 22), Rehabilitation Counseling (No. 30), and Speech-Language Pathology (No. 45).

\section{INCREASE DEGREE PRODUCITIVITY AND PROGRAM EFFICIENCY}

USF's productivity and efficiency has never been stronger. This is best evidenced by the recent Board of Governors 2012-13 performance funding awards, with USF receiving the highest amount (tied with the University of Central Florida) in recognition of its degree cost-efficiency, high percentage of graduates employed after graduation, and the high wages of graduates. 
Access to that high-quality higher education is growing significantly, equipping more and more students from a variety of different backgrounds with the skills they need for a successful lifetime career. In the last decade, USF's degree production has doubled, increasing to a record 10,950 in 2012-13. That includes students from 120 different countries, making USF one of the 40 most diverse public universities in the country and the second most diverse institution in the State University System of Florida. USF is a leader in awarding baccalaureate degrees to traditionally underrepresented groups and minority students, recognized in 2012 by Diverse magazine as $28^{\text {th }}$ among all U.S. colleges or universities in awarding undergraduate degrees to minorities. Forty-three percent of USF undergraduate students receive a federal Pell Grant (IPEDS, 2011-12).

USF is a leader in online education, named by the Guide to Online Schools as $25^{\text {th }}$ best overall among top schools offering high-quality, affordable online programs, based on data compiled by the National Center for Education Statistics - the primary federal entity for collecting and analyzing data related to education. USF currently offers 26 fully online programs at the undergraduate and graduate levels, and nearly 60 percent of all USF students take at least one online course.

USF is also proud to be one of the most veteran-friendly campuses in the country, named No. 4 nationwide by Military Times Edge in 2012. USF is one of only 16 universities in the nation selected as a Tillman Partnership University of the Pat Tillman Foundation, a selection based on innovative veteranspecific support services and a proven culture of community for military families.

USF continues to focus on initiatives that will result in improvements and/or cost savings for reinvestment. These include consolidated business operations; digitization of forms, trainings, student tracking tools and other data; restructuring of certain departments; expanded use of in-house services; maximizing classroom and office space and more. In the past year, USF has also terminated or placed on inactive status three under-performing degree programs.

\section{INCREASE THE NUMBER OF DEGREES AWARDED IN S.T.E.M. AND OTHER PROGRAMS OF STRATEGIC EMPHASIS}

USF is committed to responding to the existing, evolving, and emerging needs and opportunities of the state economy. As a result, the university's total degrees awarded in areas of strategic emphasis, including STEM fields and others, such as health sciences, grew by 7 percent in 2012-13, up to 51 percent of the total USF degrees awarded.

USF's STEM offerings are growing in key high-demand areas. In 2013, USF's Board of Trustees approved the creation of a new two-year physician assistant program, which will produce nationally certified and state licensed PAs who will help meet the critical health needs of Florida.

The university's total degrees awarded specifically in STEM fields grew by 7 percent in 2012-13, up to 50 percent of the total USF degrees awarded in areas of strategic emphasis.

Recognizing another state need in an area of strategic emphasis, USF launched a new initiative in 201213 to expand its efforts in cybersecurity. This was supported by the 2013 Legislature and Florida Governor, who included in the state budget proviso language that called for a plan to create the Florida Center for Cybersecurity, housed at USF. That plan was approved unanimously by the Board of Governors at its meeting Nov. 21 at Florida International University. It will now be transmitted to the Florida Legislature and Gov. Rick Scott for further consideration. 


\section{Narrative}

\section{Scholarship, Research and Innovation STRENGTHEN QUALITY AND REPUTATION OF SCHOLARSHIP, RESEARCH AND INNOVATION}

As one of four public universities in Florida classified by the Carnegie Foundation for the Advancement of Teaching in the top tier of research universities, USF research produces practical knowledge and products that directly benefit Florida's critical needs and boost the economy. USF has become a leader in the study and treatment of brain disease; veterans' reintegration and resilience; sustainability; infectious disease; and photovoltaic technologies. Put simply, USF research is making a major impact on the state of Florida.

USF is No. 2 in research activity among its sister institutions in the State University System, second only to the University of Florida, and that activity is growing. In FY 2013, USF was awarded a record \$413.6 million in research contracts and grants. In FY 2012, USF had a record \$451.2 million in total research expenditures, a 14 percent increase from FY 2011

USF researchers are increasingly recognized nationally and internationally. During 2012-2013, USF faculty were awarded 74 AAU, TARU, NRC and other highly prestigious awards, including the Carnegie Foundation/CASE U.S. Professor of the Year, the only two Sloan research fellowships awarded in Florida, three NSF CAREER awards, five NAI fellowships, and four Core Fulbrights, to name a few. In 2012, USF was in the top 10 of all institutions worldwide for Fellows of the American Association for the Advancement of Science, with a record 15 USF professors elected for the prestigious, AAU-recognized honor. The university founded and is home to the National Academy of Inventors (NAl), which boasts more than 2,000 inventor members and fellows spanning more than 100 U.S. universities and governmental and nonprofit research institutions and is growing rapidly. The USF chapter of the NAI has more than 270 faculty, staff, student, and alumni members who collectively hold more than 1,400 U.S. patents.

One exceptional research example is the USF Pediatric Epidemiology Center. The center, a data and technology coordinating hub for nearly every major Type 1 diabetes clinical trial worldwide, has become the epicenter for global juvenile diabetes research under the direction of Jeffrey Krischer. Krischer's research has brought nearly $\$ 500$ million in funding to USF from the National Institutes of Health, the most of any researcher in the country.

Meanwhile, USF students are increasingly afforded opportunities to help bring innovation to life, maximizing their academic experiences. The Princeton Review and Entrepreneur magazine in 2012 ranked USF's interdisciplinary entrepreneurship program among the top 25 programs in the nation-the only Florida program included.

\section{INCREASE RESEARCH AND COMMERCIALIZATION ACTIVITY}

USF has worked hard to cultivate a spirit of entrepreneurship and innovation on campus, aggressively pursuing out-of-state grants and research contracts, promoting interdisciplinary collaboration, and working to bring scientific discoveries to the market.

The USF Technology Transfer Office/Patents and Licensing continues to thrive in transferring university technologies to the marketplace through license/option agreements. In 2013, 75 license/option agreements were negotiated, which reflects a 44 percent increase from the previous year. This increase places USF in the top 25 in the U.S. when compared to other individual universities reporting to the 
Association of University Technology Managers (AUTM). USF also fostered the formation of nine start-up companies in 2013. This number of start-up companies places USF in the top 15 in the U.S. when compared to other individual universities reporting to AUTM.

The USF Research Park on the Tampa campus links researchers to businesses in need of research partnership. Occupancy of the Research Park, the core complex of which opened only eight years ago, is at 97 percent. There are currently 45 resident and eight affiliate companies focused on the business commercialization of biotechnology and life sciences research.

The Research Park is home to USF CONNECT, a network of innovation-based companies, research, government resources, and businesses development tools. This includes the USF Research Foundation and Tampa Bay Technology Incubator (TBTI), which provides a range of support services to help companies grow. To date, the incubator has worked with more than 65 companies, creating some 350 jobs in Tampa Bay and facilitating more than 130 partnerships with USF faculty.

USF CONNECT collaborated with community partners to obtain a $\$ 1$ million grant awarded from the U.S. Department of Commerce to USF and Tampa Bay WaVE (WaVE). The FirstWaVE Venture Center (Center) and FirstWaVE Accelerator Program (Accelerator) were launched in late 2012. WaVE moved into the16,000-square-foot office space located in the heart of downtown Tampa in early January 2013. Since then, numerous events have been held at the Center, now home to 14 resident companies, including the Florida Next Foundation. WaVE, USF CONNECT, and other community leaders are working with Florida Next to find a solution to the early stage capital gap in Tampa Bay and Florida. In addition, the Accelerator officially launched its first call for applications with an announcement on January 15. USF CONNECT now co-resides in the space with Tampa Bay WaVE, holding office hours at the center periodically.

USF start-up companies are automatically granted status as an Affiliate company in TBTI. Seasoned, successful entrepreneurs are linked with university researchers to support innovations with the sound business practices necessary to create a viable company. Additionally, connections are made to investors and other sources of funding that provide the essential capital for business growth.

Many companies in TBTI hire USF students as interns, and these internships frequently lead into fulltime jobs with the company after graduation. Additionally, students benefit from hands-on experiences in both the labs and the business offices, learning new skills, developing a network of contacts and enhancing their résumés.

To help prepare the next generation of researchers and entrepreneurs to fill emerging jobs and earn graduate degrees, USF is committed to providing undergraduates research opportunities across all disciplines. Through the Office for Undergraduate Research and individual departments, thousands of USF students gain valuable hands-on research experience and critical internship training each semester. The enhanced training and partnerships help create a highly skilled workforce, develop new jobs, bring new technologies to society faster, and introduce a sense of business to the university setting.

Other programs, such as the Capstone Learning Experience Courses, are designed to bring together knowledge from a certain discipline into a culminated learning experience for deeper understanding of the discipline by requiring a project, paper, proposal, or performance. Additionally, the Information Systems Decision Science Program (ISDS), located in the College of Business, partners with industry sponsors to give students new skills and experiences in doing "real world" projects while working with the industry sponsors. 


\section{INCREASE COLLABORATION AND EXTERNAL SUPPORT FOR RESEARCH ACTIVITY}

USF research enjoys broad support in the local and state community. Of USF's total $\$ 413.6$ million in external research funding in 2013 , nearly half (46 percent) came from private partnerships in the community, most from private or corporate partners.

A significant private partnership is the College of Marine Science and the BP Gulf of Mexico Research Initiative, which continues to provide funding for researching the effects of the BP oil spill of 2010. Other local and state private partnerships include: Florida Education Fund, Florida Healthy Kids Corporation, Tampa Bay Workforce Alliance and H. Lee Moffitt Cancer Center and Research Institute.

USF Sponsored Research utilizes a global software tool for identifying appropriate funding opportunities for USF faculty members, known as Pivot. Pivot allows for the most comprehensive search for funding sources and identifies researchers' expertise from within or outside of the organizations. It provides global and local connections that strengthen research by exploring new avenues for funding and collaboration-for faculty, staff researchers, and graduate students.

As one of three universities participating in the Florida High Tech Corridor Council's (FHTCC) Matching Grants Research Program (MGRP), USF is able to foster collaboration with private industry partners and increase research activity. Using FHTCC funds, Florida-based technology companies sponsoring research with the university are able to leverage their $R \& D$ budgets to increase the capabilities of the project.

This year, USF has continued to grow external support with industry partners participating in the MGRP. The program experienced a 10 percent increase in the number of research projects during 2013. Projects covered several different technology sectors, including aviation and aerospace, microelectronics and sustainable energy. The MGRP also saw a 70 percent increase in student engagements as it related to the projects.

An example of a collaboration utilizing FHTCC matching funds was the partnership between USF's College of Engineering and Northrop Grumman Corp. USF research provided a detailed investigation into analytics software used to handle "Big Data" problems in the defense industry. An evaluation on usability and integration was used to determine the cost that is required to combine different analytics software. 


\section{Narrative}

\section{Community and Business Engagement STRENGTHEN QUALITY AND REPUTATION OF COMMITMENT TO COMMUNITY AND BUSINESS ENGAGEMENT}

USF is dedicated to making an impact on state, national and global scales, both for the betterment of its student body and of the external community.

This focus has garnered accolades for USF's external engagement, including being ranked 78th nationally out of more than 1,500 higher education institutions for social mobility, research and civic engagement, according to Washington Monthly. The university was also acknowledged with a place on the 2013 President's Higher Education Community Service Honor Roll. The Honor Roll recognizes higher education institutions that reflect the values of community service and achieve meaningful outcomes in their communities.

Locally, USF makes an impact through the activities of its Center for Leadership and Civic Engagement (CLCE), which through various events and initiatives challenges students to be effective, ethical and engaged leaders. These include the annual Community Plunge, Ghandi Day of Service and the intensive daylong Stampede of Service, which has grown to become the largest community service event in USF's history, serving more than 60 organizations in the Tampa Bay community.

As a global example, USF's Ghana Scholars Program was selected by the Institute of International Education (IIE) for the 2013 Andrew Heiskell Honorable Mention Award for international partnerships, recognizing strategic, comprehensive, and innovative international partnership efforts. The program is designed to promote the exchange of ideas and address the need for capacity-building among the faculty at the Universities of Ghana and Cape Coast.

\section{INCREASE LEVELS OF COMMUNITY AND BUSINESS ENGAGEMENT}

Students and faculty at USF are encouraged to seek opportunities beyond campus to share and gain knowledge. This begins with community service and internships, and then leads to successful careers and partnerships.

One resource at USF for this purpose is the newly established Job Shop, which represented a highlight of the 2012-13 academic year. This center, on the first floor of the USF Library, helps students research prospective employers, apply for jobs and internships, and provides a new space for Career Services Staff to coach students on interview skills, resume writing and job-search strategies. In 2012-13, the Job Shop's staff conducted 50 presentations and participated in 24 outreach events, resulting in contact with more than 2,100 students.

In the external community, the Small Business Development Center at USF provides resources to thousands of entrepreneurs, business owners and executives each year in 10 west-central counties in Florida. Services include accounting, business planning, financing and taxes, technology transfer and web strategies. According to its surveys, more than 300 of the center's clients have reported opening new businesses, while those with existing enterprises reported sales revenues increasing by more than $\$ 100$ million since working with the center. Additionally, about 4,100 jobs were saved. 


\section{INCREASE COMMUNITY AND BUSINESS WORKFORCE}

USF has been recognized by the Board of Governors as the top producer of graduates who continue their education or are employed in Florida, earning $\$ 2.6$ million of the $\$ 20$ million available in performance funding to the State University System in 2012-13-the highest amount awarded. One of the metrics used in performance funding identified 52 percent of USF bachelor's graduates employed in Florida one year after graduation (FETPIP, 2010-11). Further, of the SUS institutions, USF graduates were found to have the $3^{\text {rd }}$ highest median full-time wages of undergraduates employed in Florida one year after graduation (FETPIP, 2010-11).

USF views local and state employers as educational partners in the development and preparation of its students, rather than merely consumers of graduates. Employers serve on university advisory boards, speak to classes and student groups, serve as judges for case-study projects, become involved in targeted research projects, sponsor academic challenges, offer experiential learning opportunities, attend career fairs, hold employer information sessions and conduct on-campus interviews. This has laid the groundwork for an effective employer-employee pipeline at USF.

By actively listening to needs of employers and finding ways to embed those needs into its educational efforts, USF has built a reputation for producing students that are not only academically prepared but workforce-ready. This is also true of employers, who embrace USF's discoveries and innovations, often offering their companies as "testing grounds" for students and faculty.

USF Career Services staff members, joined by their academic colleagues, work closely with employers to connect them with the graduates they need through online job postings, career fairs, on-campus interviews and various on-campus events. The Career Services Employer Relations staff assists employers in developing a customized campus recruitment plan that works for their needs and leverages their investment in reaching candidates.

The university views all employers, from small organizations to large corporations, as viable partners offering valuable employment opportunities for its graduates. USF's success is grounded in purposeful engagement built on collaboration, accommodation, mutual respect and the commitment of all stakeholders to train and employ talented USF graduates in the Tampa Bay and Florida. 


\section{Data Tables}

\section{FINANCIAL RESOURCES}

Table 1A. Education and General Revenues

Table 1B. Education and General Expenditures

Table 1C. Funding per Student FTE

Table 1D. Other Budget Entities

Table 1E. Voluntary Support of Higher Education

Table 1F. Tuition Differential Fee

PERSONNEL

Table 2A. Personnel Headcount

\section{ENROLLMENT}

Table 3A. Full-time Equivalent (FTE) Enrollment

Table 3C. Enrollment by Method of Instruction

\section{UNDERGRADUATE EDUCATION}

Table 4A. Baccalaureate Degree Program Changes in AY 2011-2012

Table 4B. Retention Rates

Table 4C. Full-time, First-Time-in-College (FTIC) Six-Year Graduation Rates

Table 4D. Full- and Part-time FTIC Graduation Rates

Table 4E. AA Transfers Graduation Rates

Table 4F. Other Transfers Graduation Rates

Table 4G. Baccalaureate Degrees Awarded

Table 4H. Baccalaureate Degrees Awarded in Areas of Strategic Emphasis

Table 4I. Baccalaureate Degrees Awarded to Underrepresented Groups

Table 4J. Baccalaureate Degrees Without Excess Credit Hours

Table 4K. Undergraduate Course Offerings

Table 4L. Faculty Teaching Undergraduates

Table 4M. Student/Faculty Ratio

Table 4N. Licensure/Certification Exam: Nursing (NCLEX)

\section{GRADUATE EDUCATION}

Table 5A. Graduate Degree Program Changes in AY 2011-2012

Table 5B. Graduate Degrees Awarded

Table 5C. Graduate Degrees Awarded in Areas of Strategic Emphasis

Table 5D. Licensure/Certification Exams for Graduate Programs

\section{RESEARCH \& ECONOMIC DEVELOPMENT}

Table 6A. Research and Development Expenditures

Table 6B. Centers of Excellence 


\section{Section 1 - Financial Resources}

\section{TABLE 1A. University Education and General Revenues}

\begin{tabular}{lrrrrr} 
& $\begin{array}{c}\mathbf{2 0 0 9 - 1 0} \\
\text { Actual }\end{array}$ & $\begin{array}{c}\mathbf{2 0 1 0 - 1 1} \\
\text { Actual }\end{array}$ & $\begin{array}{c}\mathbf{2 0 1 1 - 1 2} \\
\text { Actual }\end{array}$ & $\begin{array}{c}\mathbf{2 0 1 2 - 1 3} \\
\text { Actual }\end{array}$ & $\begin{array}{r}\mathbf{2 0 1 3 - 1 4} \\
\text { Estimates }\end{array}$ \\
\hline MAIN OPERATIONS & & & & & \\
\hline Recurring State Funds & $\$ 207,299,394$ & $\$ 229,483,736$ & $\$ 207,040,644$ & $\$ 197,695,445$ & $\$ 201,869,224$ \\
\hline Non-Recurring State Funds & $\$ 1,337,683$ & $\$ 2,579,803$ & $\$ 2,291,870$ & $-\$ 42,137,455$ & $\$ 3,190,000$ \\
\hline Tuition & $\$ 101,141,238$ & $\$ 109,884,700$ & $\$ 114,807,477$ & $\$ 118,200,604$ & $\$ 130,311,476$ \\
\hline Tuition Differential Fee & $\$ 6,856,219$ & $\$ 12,831,890$ & $\$ 19,548,371$ & $\$ 29,072,717$ & $\$ 29,499,995$ \\
\hline Misc. Fees \& Fines & $\$ 3,479,158$ & $\$ 3,096,769$ & $\$ 2,875,073$ & $\$ 2,568,555$ & $\$ 3,216,655$ \\
\hline Phosphate Research TF & $\$ 7,304,874$ & $\$ 7,330,654$ & $\$ 7,337,035$ & $\$ 0$ & $\$ 0$ \\
\hline Federal Stimulus Funds & $\$ 15,853,697$ & $\$ 15,169,662$ & $\$ 0$ & $\$ 0$ & $\$ 0$ \\
\hline SUBTOTAL & $\$ 343,272,263$ & $\$ \mathbf{3 8 0 , 3 7 7 , 2 1 4}$ & $\$ 353,900,470$ & $\$ 305,399,866$ & $\$ 368,087,350$
\end{tabular}

HEALTH SCIENCE CENTER / MEDICAL SCHOOL

\begin{tabular}{lrrrrr}
\hline Recurring State Funds & $\$ 61,549,150$ & $\$ 61,824,195$ & $\$ 63,127,971$ & $\$ 65,793,008$ & $\$ 70,505,598$ \\
\hline Non-Recurring State Funds & $\$ 0$ & $\$ 1,175,000$ & $\$ 250,000$ & $\$ 0$ & $\$ 1,250,000$ \\
\hline Tuition & $\$ 29,988,216$ & $\$ 32,942,009$ & $\$ 41,065,438$ & $\$ 48,203,644$ & $\$ 49,938,942$ \\
\hline Tuition Differential Fee & $\$ 501,511$ & $\$ 947,321$ & $\$ 1,703,379$ & $\$ 2,956,633$ & $\$ 3,274,040$ \\
\hline Misc. Fees \& Fines & $\$ 1,331$ & $\$ 1,280$ & $\$ 2,568$ & $\$ 41,978$ & $\$ 0$ \\
\hline Phosphate Research TF & $\$ 0$ & $\$ 0$ & $\$ 0$ & $\$ 0$ & $\$ 0$ \\
\hline Federal Stimulus Funds & $\$ 4,569,090$ & $\$ 4,351,772$ & $\$ 0$ & $\$ 0$ & $\$ 0$ \\
\hline SUBTOTAL & $\$ 96,609,298$ & $\$ 101,241,577$ & $\$ 106,149,356$ & $\$ 116,995,263$ & $\$ 124,968,580$
\end{tabular}

\section{TOTAL}

Recurring State Funds: State recurring funds include general revenue and lottery education \& general (E\&G) appropriations and any administered funds provided by the state, including annual adjustments of risk management insurance premiums for the estimated year. This does not include technical adjustments or transfers made by universities after the appropriation. Please note: for estimated 2012-13 this figure includes the non-recurring $\$ 300 \mathrm{M}$ system budget reduction. - Source: For actual years, SUS Final Amendment Packages; for estimated year the 2012-13 Allocation Summary and Workpapers (Total E\&G general revenue \& lottery minus non-recurring) and Board of Governors staff calculations for risk management insurance adjustments. Non-Recurring State Funds: State non-recurring funds include general revenue and lottery education \& general appropriations and any administered funds provided by the state. This does not include technical adjustments or transfers made by Universities after the appropriation - Source: non-recurring appropriations section of the annual Allocation Summary and Workpapers document and all other non-recurring budget amendments allocated later in the fiscal year. Tuition: Actual resident \& non-resident tuition revenues collected from students, net of fee waivers. - Source: Operating Budget, Report 625 Schedule I-A. Tuition Differential Fee: Actual tuition differential revenues collected from undergraduate students - Source: Operating Budget, Report 625 - Schedule I-A. Miscellaneous Fees \& Fines: Other revenue collections include items such as application fees, late registration fees, library fines, miscellaneous revenues. This is the total revenue from Report 625 minus tuition and tuition differential fee revenues. This does not include local fees - Source: Operating Budget, Report 625 - Schedule I-A. Phosphate Research Trust Fund: State appropriation for the Florida Industrial and Phosphate Research Institute at the University of South Florida (for history years through 201112); beginning 2012-13 the Phosphate Research Trust Fund is appropriated through Florida Polytechnic University. Other Operating Trust Funds- For UF-IFAS and UF-HSC, actual revenues from the Incidental Trust Funds and Operations \& Maintenance Trust Fund are provided by the University of Florida. Source: Final Amendment Package. Federal Stimulus Funds: Non-recurring American Recovery and Reinvestment Act funds appropriated by the state - Source: SUS Final Amendment Package. 
Section 1 - Financial Resources (continued) TABLE 1B. University Education and General Expenditures

\begin{tabular}{|c|c|c|c|c|c|}
\hline & $\begin{array}{c}2009-10 \\
\text { Actual }\end{array}$ & $\begin{array}{c}2010-11 \\
\text { Actual }\end{array}$ & $\begin{array}{c}2011-12 \\
\text { Actual }\end{array}$ & $\begin{array}{l}2012-13 \\
\text { Actual }^{*}\end{array}$ & $\begin{array}{c}\text { 2013-14 } \\
\text { Estimates }^{* *}\end{array}$ \\
\hline \multicolumn{6}{|l|}{ MAIN OPERATIONS } \\
\hline Instruction/Research & $\$ 210,298,415$ & $\$ 216,495,768$ & $\$ 206,584,000$ & $\$ 251,411,459$ & $\$ 278,512,006$ \\
\hline Administration and Support & $\$ 15,737,708$ & $\$ 18,202,340$ & $\$ 19,043,513$ & $\$ 24,357,579$ & $\$ 17,811,824$ \\
\hline PO\&M & $\$ 29,960,884$ & $\$ 29,586,468$ & $\$ 30,315,270$ & $\$ 36,507,797$ & $\$ 35,230,391$ \\
\hline Student Services & $\$ 17,871,933$ & $\$ 17,063,333$ & $\$ 14,849,300$ & $\$ 13,239,624$ & $\$ 13,103,679$ \\
\hline Library/Audio Visual & $\$ 11,694,131$ & $\$ 11,219,137$ & $\$ 10,777,212$ & $\$ 7,887,471$ & $\$ 17,028,047$ \\
\hline Other & $\$ 2,857,226$ & $\$ 2,854,224$ & $\$ 6,470,660$ & $\$ 6,957,842$ & $\$ 6,402,006$ \\
\hline TOTAL & $\$ 288,420,297$ & $\$ 295,421,270$ & $\$ 288,039,955$ & $\$ 340,361,772$ & $\$ 368,087,953$ \\
\hline
\end{tabular}

HEALTH SCIENCE CENTER / MEDICAL SCHOOL

\begin{tabular}{lrrrrr}
\hline Instruction/Research & $\$ 68,082,738$ & $\$ 76,521,544$ & $\$ 76,382,108$ & $\$ 95,673,445$ & $\$ 113,762,366$ \\
\hline Administration and Support & $\$ 5,033,768$ & $\$ 6,375,343$ & $\$ 5,076,837$ & $\$ 8,132,708$ & $\$ 6,234,449$ \\
\hline PO\&M & $\$ 84,684$ & $\$ 1,373,059$ & $\$ 1,800,847$ & $\$ 7,019,397$ & $\$ 4,338,130$ \\
\hline Library/Audio Visual & $\$ 2,473,154$ & $\$ 2,437,820$ & $\$ 3,043,160$ & $\$ 2,921,295$ & $\$ 2,316,140$ \\
\hline Teaching Hospital \& Clinics & $\$ 0$ & $\$ 0$ & $\$ 0$ & $\$ 0$ & $\$ 0$ \\
\hline Student Services, and Other & $\$ 0$ & $\$ 1,640$ & $\$ 0$ & $\$ 0$ & $\$ 0$ \\
\hline TOTAL & $\$ 75,674,344$ & $\$ 86,709,406$ & $\$ 86,302,952$ & $\$ 113,746,845$ & $\$ 126,651,085$
\end{tabular}

TOTAL

$\$ 364,094,641 \quad \$ 382,130,676 \quad \$ 374,342,907 \quad \$ 454,108,617 \quad \$ 494,739,038$

The table reports the actual and estimated amount of expenditures from revenues appropriated by the legislature for each fiscal year. The expenditures are classified by Program Component (i.e., Instruction/Research, PO\&M, Administration, etc...) for activities directly related to instruction, research and public service. The table does not include expenditures classified as non-operating expenditures (i.e., to service assetrelated debts), and therefore excludes a small portion of the amount appropriated each year by the legislature. Note*: FY 2012-2013 reflects a change in reporting expenditures from prior years due to the new carry-forward reporting requirement as reflected in the 2013-2014 SUS Operating Budget Reports. Since these expenditures will now include carry-forward expenditures, these data are no longer comparable to the current-year revenues reported in table 1A, or prior year expenditures in table 1B.. Note ${ }^{* *}$ : Estimated year amounts are from FY 2013-14 appropriations only and do not include anticipated expenditures from university carry-forward funds.

Instruction \& Research: Includes expenditures for state services related to the instructional delivery system for advanced and professional education. Includes functions such as; all activities related to credit instruction that may be applied toward a postsecondary degree or certificate; nonproject research and service performed to maintain professional effectives; individual or project research; academic computing support; academic source or curriculum development. Source: Operating Budget Summary - Expenditures by Program Activity (or Report 645). Administration \& Support Services: Expenditures related to the executive direction and leadership for university operations and those internal management services which assist and support the delivery of academic programs. Source: Operating Budget Summary - Expenditures by Program Activity (or Report 645). PO\&M: Plant Operations \& Maintenance expenditures related to the cleaning and maintenance of existing grounds, the providing of utility services, and the planning and design of future plant expansion and modification. Student Services: Includes resources related to physical, psychological, and social well being of the student. Includes student service administration, social and cultural development, counseling and career guidance, financial aid, and student admissions and records. Other: includes Institutes and Research Centers, Radio/TV, Museums and Galleries, Intercollegiate Athletics, Academic Infrastructure Support Organizations. Source: Operating Budget Summary - Expenditures by Program Activity (or Report 645). 


\section{Section 1 - Financial Resources (continued)}

\section{TABLE 1C. State Funding per Full-Time Equivalent (FTE) Student} (Data provided by USF)

\begin{tabular}{lrrrrr} 
& $\begin{array}{c}\mathbf{2 0 0 8 - 0 9} \\
\text { Actual }\end{array}$ & $\begin{array}{r}\mathbf{2 0 0 9 - 1 0} \\
\text { Actual }\end{array}$ & $\begin{array}{r}\mathbf{2 0 1 0 - 1 1} \\
\text { Actual }\end{array}$ & $\begin{array}{r}\mathbf{2 0 1 1 - 1 2} \\
\text { Actual }\end{array}$ & $\begin{array}{r}\mathbf{2 0 1 2 - 1 3} \\
\text { Actual }\end{array}$ \\
\hline Appropriated Funding per FTE & & & & & \\
\hline$\quad$ General Revenue & $\$ 6,951$ & $\$ 5,758$ & $\$ 5,715$ & $\$ 5,729$ & $\$ 4,332$ \\
$\quad$ Lottery Funds & $\$ 934$ & $\$ 836$ & $\$ 933$ & $\$ 994$ & $\$ 765$ \\
$\quad \begin{array}{l}\text { Tuition \& Fees } \\
\text { Other Trust Funds }\end{array}$ & $\$ 3,388$ & $\$ 3,620$ & $\$ 4,156$ & $\$ 4,835$ & $\$ 5,358$ \\
$\quad$ TOTAL & $\$ 0$ & $\$ 757$ & $\$ 474$ & $\$ 61$ & $\$ 0$ \\
Actual Funding per FTE & $\$ 11,273$ & $\$ 10,970$ & $\$ 11,278$ & $\$ 11,619$ & $\$ 10,455$ \\
\hline Tuition \& Fees & & & & & \\
$\quad$ TOTAL & $\$ 3,388$ & $\$ 3,620$ & $\$ 3,868$ & $\$ 4,407$ & $\$ 4,909$ \\
\end{tabular}

Notes: (1) FTE is based on actual FTE, not funded FTE; (2) does not include Health-Science Center funds or FTE; (3) FTE for these metrics uses the standard IPEDS definition of FTE, equal to 30 credit hours for undergraduates and 24 for graduates; and (4) actual funding per student is based on actual tuition and E\&G fees (does not include local fees) collected. Sources: Appropriated totals from the annual Final Amendment Package data. Estimated year data from the Allocation Summary document. Actual Student Fees from the Operating Budget 625 reports. This does not include appropriations for special units (i.e., IFAS, Health Science Centers, and Medical Schools). Tuition and fee revenues include tuition and tuition differential fee and E\&G fees (i.e., application, late registration, and library fees/fines). Other local fees that do not support E\&G activities are not included here (see Board of Governors Regulation 7.003). This data is not adjusted for inflation.

TABLE 1D. University Other Budget Entities

$\begin{array}{cc}2009-10 & 2010-11 \\ \text { Actual } & \text { Actual }\end{array}$

2011-12 Actual

$\$ 156,099,807$

$\$ 130,615,398$ at the USF System level

Expenditures

\section{Contracts \& Grants}

Revenues

Expenditures

Previously reported only

at the USF System level

$\$ 249,719,038$

$\$ 305,717,745$

$\$ 273,377,821$

$\$ 305,315,644$

$\$ 372,304,136$

$\$ 379,342,792$

\section{Leal Funds}

Revenues

Expenditures

Faculty Practice Plans

$\begin{array}{llllll}\text { Revenues } & \$ 174,727,927 & \$ 183,622,430 & \$ 194,997,543 & \$ 199,933,005 & \$ 210,391,952 \\ \text { Expenditures } & \$ 173,643,913 & \$ 182,116,435 & \$ 196,288,464 & \$ 198,051,785 & \$ 210,391,952\end{array}$

Notes: Revenues do not include transfers. Expenditures do not include non-operating expenditures. Auxiliary Enterprises are self supported through fees, payments and charges. Examples include housing, food services, bookstores, parking services, health centers. Contract \& Grants resources are received from federal, state or private sources for the purposes of conducting research and public service activities. Local Funds are associated with student activity (supported by the student activity fee), student financial aid, concessions, intercollegiate athletics, technology fee, green fee, and student life \& services fee. Faculty Practice Plan revenues/receipts are funds generated from faculty practice plan activities. Faculty Practice Plan expenditures include all expenditures relating to the faculty practice plans, including transfers between other funds and/or entities. This may result in double counting in information presented within the annual report. Source: Operating Budget, Report 615. 


\section{Section 1 - Financial Resources (continued)}

\section{TABLE 1E. Voluntary Support of Higher Education}

\begin{tabular}{cccccc} 
& $2007-08$ & $2008-09$ & $2009-10$ & $2010-11$ & $2011-12$ \\
\hline $\begin{array}{c}\text { Endowment Value } \\
(\$ 1000 \text { s })\end{array}$ & & & & \\
\hline $\begin{array}{c}\text { Gifts Received } \\
(\$ 1000 \text { s })\end{array}$ & & This data is only available for the USF System. & \\
\hline $\begin{array}{c}\text { Percentage of } \\
\text { Alumni Donors }\end{array}$ & & & & \\
\hline
\end{tabular}

Notes: Endowment value at the end of the fiscal year, as reported in the annual NACUBO Endowment Study. Gifts Received as reported in the Council for Aid to Education's Voluntary Support of Education (VSE) survey in the section entitled "Gift Income Summary," this is the sum of the present value of all gifts (including outright and deferred gifts) received for any purpose and from all sources during the fiscal year, excluding pledges and bequests. (There's a deferred gift calculator at www.cae.org/vse.) The present value of non-cash gifts is defined as the tax deduction to the donor as allowed by the IRS. Percentage of Alumni Donors as reported in the Council for Aid to Education's Voluntary Support of Education (VSE) survey in the section entitled "Additional Details," this is the number of alumni donors divided by the total number of alumni, as of the end of the fiscal year. "Alumni," as defined in this survey, include those holding a degree from the institution as well as those who attended the institution but did not earn a degree.

\section{TABLE 1F. Tuition Differential Fees (TDF)}

\begin{tabular}{lccc} 
& $\mathbf{2 0 1 0 - 1 1}$ & $\mathbf{2 0 1 1 - 1 2}$ & $\mathbf{2 0 1 2 - 1 3}$ \\
\hline TDF Revenues Generated & $\$ 12,477,422$ & $\$ 19,548,371$ & $\$ 32,029,350$ \\
\hline Students Receiving TDF Funded Award & 2,748 & 4,505 & 8,014 \\
Total Value of TDF Funded Financial Aid Awards & $\$ 1,362$ & $\$ 1,302$ & $\$ 1,262$
\end{tabular}

\section{Florida Student Assistance Grant (FSAG) Eligible Students}

\begin{tabular}{lccc}
\hline Number of Eligible Students & 6,668 & 6,936 & $\$ 11,673$ \\
\hline Number Receiving a TDF Waiver & 0 & 0 & 0 \\
Total Value of TDF Waivers & $\$ 0$ & $\$ 0$ & $\$ 0$
\end{tabular}

Note: TDF Revenues Generated refers to actual tuition differential revenues collected from undergraduate students as reported on the Operating Budget, Report 625 - Schedule I-A. Students Receiving TDF Funded Award reports the number of unduplicated students who have received a financial aid award that was funded by tuition differential revenues. Value of TDF Funded Award refers to the average value of financial aid awards funded by the the Tuition Differential Fee funds. Florida Student Assistance Grant (FSAG) Eligible Students: Number of Eligible Students refers to total annual unduplicated count of undergraduates at the institution who are eligible for FSAG in the academic year, whether or not they received FSAG awards. Number Receiving a TDF Waiver refers to annual unduplicated count of FSAG-eligible students receiving a waiver, partial or full, of the tuition differential fees at the institution during the academic year, regardless of the reason for the waiver. Value of TDF Waivers refers to the average value of waivers provided to FSAG-eligible undergraduates at the institution during the academic year, regardless of the reason for the waiver. 


\section{Section 2 - Personnel}

TABLE 2A. Personnel Headcount (in Fall term only)

\begin{tabular}{|c|c|c|c|c|c|}
\hline & 2008 & 2009 & 2010 & 2011 & 2012 \\
\hline \multicolumn{6}{|l|}{ Full-time Employees } \\
\hline Tenured Faculty & 660 & 683 & 691 & 684 & 661 \\
\hline Tenure-track Faculty & 318 & 297 & 309 & 338 & 329 \\
\hline Non-Tenure Track Faculty & 416 & 444 & 466 & 457 & 469 \\
\hline Instructors Without Faculty Status & 0 & 0 & 0 & 0 & 0 \\
\hline Graduate Assistants/Associates & 0 & 0 & 0 & 0 & 0 \\
\hline Non-Instructional Employees & 3,694 & 3,740 & 3,915 & 4,100 & 3,964 \\
\hline FULL-TIME SUBTOTAL & 5,079 & 5,164 & 5,381 & 5,579 & 5,423 \\
\hline \multicolumn{6}{|l|}{ Part-time Employees } \\
\hline Tenured Faculty & 55 & 57 & 53 & 45 & 55 \\
\hline Tenure-track Faculty & 22 & 21 & 25 & 19 & 19 \\
\hline Non-Tenure Track Faculty & 132 & 132 & 137 & 190 & 526 \\
\hline Instructors Without Faculty Status & 0 & 0 & 3 & 0 & 0 \\
\hline Graduate Assistants/Associates & 1,746 & 1,835 & 2,034 & 2,026 & 1,988 \\
\hline Non-Instructional Employees & 118 & 156 & 143 & 209 & 778 \\
\hline PART-TIME SUBTOTAL & 2,073 & 2,201 & 2,392 & 2,489 & 3,366 \\
\hline TOTAL & 7,152 & 7,365 & 7,773 & 8,068 & 8,789 \\
\hline
\end{tabular}

Note: This table is based on the annual IPEDS Human Resources Survey, and provides full- and part-time medical and non-medical staff by faculty status and primary function/occupational activity. Tenured and Tenure-Track Faculty include those categorized within instruction, research, or public service. Non-Tenure Track Faculty includes adjunct faculty (on annual and less than annual contracts) and faculty on multi-year contracts categorized within instruction, research, or public service. Instructors Without Faculty Status includes postdoctoral research associates, and individuals hired as a staff member primarily to do research on a 3-year contract without tenure eligibility categorized within instruction, research, or public service. Non-Instructional Employees includes all executive, administrative and managerial positions regardless of faculty status; as well as, other support and service positions regardless of faculty status. Note: The universities vary on how they classify adjuncts (some include them as non-tenure track faculty while others do not consider them faculty and report them as instructors without faculty status) and part-time non-instructional employees. 


\section{Section 3 - Enrollment}

TABLE 3A. Full-Time Equivalent (FTE) Enrollment (Data provided by USF)

2010-11

State-

Funded
2011-12 State-
Funded
2012-13

StateFunded

Actual

FLORIDA RESIDENTS

\begin{tabular}{lcc|cc|cc}
\hline LOWER-DIVISION & 8,720 & 8,427 & 8,720 & 8,129 & 8,617 & 7,833 \\
UPPER-DIVISION & 10,583 & 11,191 & 11,077 & 11,964 & 10,493 & 11,994 \\
MASTER'S (GRAD I) & 3,167 & 3,175 & 3,270 & 3,139 & 2,775 & 3,075 \\
DOCTORAL (GRAD II) & 855 & 1,003 & 855 & 973 & 623 & 934 \\
\hline TOTAL & $\mathbf{2 3 , 3 2 5}$ & $\mathbf{2 3 , 7 9 6}$ & $\mathbf{2 3 , 9 2 2}$ & $\mathbf{2 4 , 2 0 5}$ & $\mathbf{2 2 , 5 0 8}$ & $\mathbf{2 3 , 8 3 6}$
\end{tabular}

NON-FLORIDA RESIDENTS

\begin{tabular}{lcc|cc|cc} 
LOWER-DIVISION & $\cdot$ & 384 & $\cdot$ & 468 & $\cdot$ & 589 \\
UPPER-DIVISION & $\cdot$ & 393 & $\cdot$ & 447 & $\cdot$ & 531 \\
MASTER'S (GRAD I) & $\cdot$ & 476 & $\cdot$ & 529 & $\cdot$ & 620 \\
DOCTORAL (GRAD II) & $\cdot$ & 506 & $\cdot$ & 579 &. & 622 \\
\hline TOTAL & $\mathbf{1 , 3 0 2}$ & $\mathbf{1 , 7 5 9}$ & $\mathbf{1 , 3 0 2}$ & $\mathbf{2 , 0 2 3}$ & $\mathbf{1 , 3 0 2}$ & $\mathbf{2 , 3 6 3}$
\end{tabular}

TOTAL FTE

\begin{tabular}{|c|c|c|c|c|c|c|}
\hline LOWER-DIVISION & . & 8,811 & & 8,597 & . & 8,422 \\
\hline UPPER-DIVISION & . & 11,584 & . & 12,411 & . & 12,525 \\
\hline MASTER'S (GRAD I) & . & 3,651 & . & 3,668 & . & 3,695 \\
\hline DOCTORAL (GRAD II) & . & 1,509 & . & 1,552 & . & 1,556 \\
\hline TOTAL & 23,213 & 25,555 & 23,810 & 26,228 & 23,810 & 26,198 \\
\hline $\begin{array}{l}\text { TOTAL } \\
\text { US Definition }\end{array}$ & 30,951 & 34,073 & 31,747 & 34,971 & 31,747 & 34,931 \\
\hline
\end{tabular}

\section{HEADCOUNT FOR MEDICAL DOCTORATES}

\begin{tabular}{l|cc|cc|cc|}
\hline RESIDENTS & 480 & 449 & 480 & 444 & 480 & 456 \\
NON-RESIDENTS & 0 & 24 & 0 & 39 & 0 & 42 \\
\hline TOTAL & 480 & 473 & 480 & 483 & 480 & 498 \\
\hline
\end{tabular}

Notes: Full-time Equivalent (FTE) student is a measure of instructional effort (and student activity) that is based on the number of credit hours that students enroll. FTE is based on the Florida definition, which divides undergraduate credit hours by 40 and graduate credit hours by 32 (US definition based on Undergraduate FTE $=30$ and Graduate FTE $=24$ credit hours). Funded enrollment as reported in the General Appropriations Act and set by the legislature. Actual enrollment only reports 'state-fundable' FTE as reported by Universities to the Board of Governors in the Student Instruction File (SIF). Totals are actual and may not equal sum of reported student levels due to rounding of student level FTE. 


\section{Section 3 - Enrollment (continued)}

\section{TABLE 3C. Full-Time Equivalent (FTE) Enrollment by Method of Instruction (Data provided by USF)}

2010-11 $2011-12$

2012-13

\section{TRADITIONAL}

LOWER-DIVISION

UPPER-DIVISION

7,497

9,220

MASTER'S (GRAD I)

2,543

1,452

20,712

TOTAL
22

289

97

9

416
7,217

9,365

2,600

1,490

20,672
7,127

9,168

2,551

1,519

20,365
HYBRID

$\begin{array}{lrrr}\text { LOWER-DIVISION } & 22 & 42 & 83 \\ \text { UPPER-DIVISION } & 289 & 302 & 344 \\ \text { MASTER'S (GRAD I) } & 97 & 141 & 136 \\ \text { DOCTORAL (GRAD II) } & 9 & \mathbf{5} & 8 \\ \text { TOTAL } & 416 & 489 & \mathbf{5 7 1}\end{array}$

DISTANCE LEARNING
LOWER-DIVISION
UPPER-DIVISION
MASTER'S (GRAD I)
DOCTORAL (GRAD II)

TOTAL

\section{1,292}

2,075

1,010

48

4,425

\section{1,338}

2,743

928

61

5,070
1,216

3,016

1,020

67

TOTAL

LOWER-DIVISION
UPPER-DIVISION
MASTER'S (GRAD I)
DOCTORAL (GRAD II)
TOTAL

TOTAL

8,81
11,58
3,650
1,509

25,553

$\begin{array}{rr}8,597 & 8,426 \\ 12,410 & 12,528 \\ 3,669 & 3,707 \\ 1,555 & 1,593\end{array}$

26,231

26,254

Note: Full-time Equivalent (FTE) student is a measure of instructional effort (and student activity) that is based on the number of credit hours that students enroll. FTE is based on the Florida definition, which divides undergraduate credit hours by 40 and graduate credit hours by 32 . Distance Learning is a course in which at least 80 percent of the direct instruction of the course is delivered using some form of technology when the student and instructor are separated by time or space, or both (per 1009.24(17), F.S.). Hybrid is a course where $50 \%$ to $79 \%$ of the instruction is delivered using some form of technology, when the student and instructor are separated by time or space, or both (per SUDS data element 2052). Traditional (and Technology Enhanced) refers to primarily face to face instruction utilizing some form of technology for delivery of supplemental course materials for no more than $49 \%$ of instruction (per SUDS data element 2052). Totals are actual and may not equal sum of reported student levels due to rounding of student level FTE. Total FTE are equal in tables 3A, 3B. 


\section{Section 4 - Undergraduate Education}

\section{TABLE 4A. Baccalaureate Degree Program Changes in AY 2012-13}

\begin{tabular}{|c|c|c|c|c|c|}
\hline Title of Program & $\begin{array}{c}\text { Six-digit } \\
\text { CIP } \\
\text { Code }\end{array}$ & $\begin{array}{c}\text { Degree } \\
\text { Level }\end{array}$ & $\begin{array}{l}\text { Date of } \\
\text { UBOT } \\
\text { Action }\end{array}$ & $\begin{array}{l}\text { Starting } \\
\text { or Ending } \\
\text { Term }\end{array}$ & Comments \\
\hline \multicolumn{6}{|l|}{ New Programs } \\
\hline Behavioral Healthcare & 44.0000 & $\mathrm{~B}$ & $6 / 14 / 2012$ & Fall 1012 & \\
\hline \multicolumn{6}{|l|}{ Terminated Programs } \\
\hline \multicolumn{6}{|l|}{ None } \\
\hline & & & & & \\
\hline & & & & & \\
\hline \multicolumn{6}{|l|}{ Inactive Programs } \\
\hline \multicolumn{6}{|l|}{ None } \\
\hline & & & & & \\
\hline & & & & & \\
\hline \multicolumn{6}{|c|}{ New Programs Considered By University But Not Approved } \\
\hline \multicolumn{6}{|c|}{ None } \\
\hline
\end{tabular}

Note: This table does not include new majors or concentrations added under an existing degree program CIP Code. This table reports the new and terminated program changes based on Board action dates between May 5, 2012 and May 4, 2013.

New Programs are proposed new degree programs that have been completely through the approval process at the university and, if appropriate, the Board of Governors. Does not include new majors or concentrations added under an existing degree program CIP Code.

Terminated Programs are degree programs for which the entire CIP Code has been terminated and removed from the university's inventory of degree programs. Does not include majors or concentrations terminated under an existing degree program CIP Code if the code is to remain active on the academic degree inventory.

Inactive Programs are degree programs for which enrollments have been temporarily suspended for the entire CIP Code, but the program CIP Code has not been terminated. Does not include majors or concentrations suspended under an existing degree program CIP Code if the code is to remain active on the academic degree inventory and new enrollments in any active major will be reported.

New Programs Considered by University But Not Approved includes any programs considered by the university board of trustees, or any committee of the board, but not approved for implementation. Also include any programs that were returned prior to board consideration by the university administration for additional development, significant revisions, or re-conceptualization; regardless of whether the proposal was eventually taken to the university board for approval. Count the returns once per program, not multiple times the proposal was returned for revisions, unless there is a total re-conceptualization that brings forward a substantially different program in a different CIP Code. 


\section{Section 4 - Undergraduate Education (continued)}

\section{TABLE 4B. Full-time, First-Time-in-College (FTIC) Retention Rates Retained in the Second Fall Term at Same University}

\begin{tabular}{cccccc} 
& $\mathbf{2 0 0 8 - 0 9}$ & $\mathbf{2 0 0 9 - 1 0}$ & $\mathbf{2 0 1 0 - 1 1}$ & $\mathbf{2 0 1 1 - 1 2}$ & $\begin{array}{c}\mathbf{2 0 1 2 - 1 3} \\
\text { Preliminary }\end{array}$ \\
\hline Cohort Size & 4,015 & 3,814 & 4,477 & 3,451 & 3,825 \\
\hline \% Retained & $86 \%$ & $88 \%$ & $86 \%$ & $87 \%$ & $89 \%$ \\
\hline $\begin{array}{c}\% \text { Retained } \\
\text { with GPA of 2.0 or higher }\end{array}$ & $84 \%$ & $85 \%$ & $84 \%$ & $86 \%$ & $88 \%$
\end{tabular}

Notes: Cohorts are based on undergraduate students who enter the institution in the Fall term (or Summer term and continue into the Fall term). Percent Retained is based on student enrollment in the Fall term following their first year. Percent Retained with GPA Above 2.0 is based on student enrollment in the Fall term following their first years for those students with a GPA of 2.0 or higher at the end of their first year (Fall, Spring, Summer). The most recent year of Retention data is based on preliminary data (SIFP file) that is comparable to the final data (SIF file) but may be revised in the following years based on changes in student cohorts.

\section{TABLE 4C. Full-time, First-Time-in-College (FTIC) Six-Year Graduation Rates}

\begin{tabular}{lccccc} 
Term of Entry & $\mathbf{2 0 0 3 - 0 9}$ & $\mathbf{2 0 0 4 - 1 0}$ & $\mathbf{2 0 0 5 - 1 1}$ & $\mathbf{2 0 0 6 - 1 2}$ & $\begin{array}{c}\mathbf{2 0 0 7 - 1 3} \\
\text { Preliminary }\end{array}$ \\
\hline \multicolumn{1}{c}{ Cohort Size } & 4,703 & 3,979 & 3,926 & 4,000 & 3,905 \\
\hline$\%$ Graduated & $47 \%$ & $52 \%$ & $52 \%$ & $57 \%$ & $63 \%$ \\
\hline$\%$ Still Enrolled & $10 \%$ & $9 \%$ & $9 \%$ & $8 \%$ & $6 \%$ \\
\hline$\%$ Success Rate & $57 \%$ & $61 \%$ & $61 \%$ & $65 \%$ & $69 \%$
\end{tabular}

Notes: Cohorts are based on undergraduate students who enter the institution in the Fall term (or Summer term and continue into the Fall term). Percent Graduated is based on federal rate and does not include students who originally enroll as part-time students, or who transfer into the institution. This metric complies with the requirements of the federal Student Right to Know Act that requires institutions to report the completion status at $150 \%$ of normal time (or six years). Success Rate measures the percentage of an initial cohort of students who have either graduated or are still enrolled at the same university. Since degrees can be awarded after the last semester of coursework, the most recent year of data in this table provides preliminary data that may change with the addition of "late degrees". Late degrees reported in conjunction with the IPEDS Graduation Rate Survey due in mid-April will be reflected in the following year. 


\section{Section 4 - Undergraduate Education (continued)}

TABLE 4D. FTIC Progression and Graduation Rates (includes Full- and Part-time students)

\section{4 - Year Rates}

2005-09 2006-10

Cohort

4,231

4212

$24 \%$

$41 \%$
$28 \%$

$40 \%$
$35 \%$

$39 \%$
2009-13

2007-11 3,963
2008-12 4,086
Preliminary

3,851

\section{From Same University}

$\%$ Graduated
$\%$ Still Enrolled

\section{$2 \%$}

$4 \%$
$2 \%$

$4 \%$
$2 \%$

$4 \%$
$38 \%$

$37 \%$
$42 \%$

$34 \%$

From Other SUS University

\% Still Enrolled

$\%$ Graduated

$26 \%$

$30 \%$

$36 \%$

$39 \%$

$44 \%$

\% Still Enrolled

$45 \%$

$44 \%$

$43 \%$

$41 \%$

$37 \%$

$\%$ Success Rate

$71 \%$

$74 \%$

$79 \%$

$80 \%$

$81 \%$

\section{6 - Year Rates}

2003-09

Cohort

4,914

2004-10

2005-11

4,231

$46 \%$

$10 \%$
$51 \%$

$9 \%$
$51 \%$

$9 \%$
$56 \%$

$8 \%$
$2 \%$

$4 \%$

$\%$ Still Enrolled

From Other SUS University

$\%$ Graduated

$\%$ Still Enrolled
$6 \%$

$2 \%$
$6 \%$

$3 \%$
$5 \%$

$2 \%$
$5 \%$

$2 \%$
2007-13

Preliminary

3,963

\section{From State University System}

\% Graduated
$\%$ Still Enrolled
$\%$ Success Rate

$52 \%$

$13 \%$

$64 \%$
$57 \%$

$12 \%$

$69 \%$

$56 \%$
$11 \%$
$67 \%$

$56 \%$
$11 \%$
$67 \%$
$61 \%$

$10 \%$

$71 \%$
$62 \%$

$6 \%$

Notes: First-time-in-college (FTIC) cohort is defined as undergraduates entering in fall term (or summer continuing to fall) with fewer than 12 hours earned since high school graduation. (1) Cohorts are based on undergraduate students who enter the institution in the Fall term (or Summer term and continue into the Fall term). Students of degree programs longer than four years (eg, PharmD) are included in the cohorts. The initial cohorts are revised to remove students, who have allowable exclusions as defined by IPEDS, from the cohort. (2) Success Rate measures the percentage of an initial cohort of students who have either graduated or are still enrolled. (3) Since degrees can be awarded after the last semester of coursework, the most recent year of data in this table provides preliminary graduation rate data that may change with the addition of "late degrees". Late degrees reported in conjunction with the IPEDS Graduation Rate Survey due in mid-April will be reflected in the following year. 


\section{Section 4 - Undergraduate Education (continued)}

\section{TABLE 4E. AA Transfer Progression and Graduation Rates}

2 - Year Rates

2007-09 2008-10

2009-11

2010-12

2011-13

Cohort

1,711

1,969

1,815

1,932

Preliminary

2,009

From Same University

$\%$ Graduated

$\%$ Still Enrolled

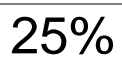

$59 \%$
$26 \%$

$60 \%$
$28 \%$

$60 \%$
$28 \%$

$59 \%$
$27 \%$

$58 \%$

\section{From Other SUS University}

$\begin{array}{lccccc}\% \text { Graduated } & 1 \% & 1 \% & 0 \% & 0 \% & 0 \% \\ \% \text { Still Enrolled } & 3 \% & 2 \% & 2 \% & 2 \% & 2 \%\end{array}$

\section{From State University System}

\% Graduated
$\%$ Still Enrolled
$\%$ Success Rate
$26 \%$

$62 \%$

$88 \%$

\section{$26 \%$}

$62 \%$

$89 \%$
$28 \%$

$62 \%$

$91 \%$
$28 \%$

$61 \%$

$89 \%$
$28 \%$ $60 \%$

$88 \%$

\section{4 - Year Rates}

2005-09

1,397

$\frac{2006-10}{1,538}$

$59 \%$

$13 \%$
$62 \%$

$13 \%$
$62 \%$

$11 \%$

1,711

1,711

2008-12

1,969

2009-13 Preliminary

1,815

From Same University
\% Graduated
\% Still Enrolled

\section{From Other SUS University}

$\%$ Graduated
$\%$ Still Enrolled

\section{$4 \%$}

$2 \%$

$3 \%$
$2 \%$
$3 \%$
$2 \%$

$65 \%$

$11 \%$
$68 \%$

$9 \%$

\section{From State University System}
$\%$ Graduated
\% Still Enrolled
\% Success Rate

$63 \%$

$15 \%$

$78 \%$
$64 \%$

$14 \%$

$78 \%$

$65 \%$
$14 \%$
$79 \%$

$2 \%$
$1 \%$

$1 \%$
$3 \%$

$1 \%$

Notes: AA Transfer cohort is defined as undergraduates entering in the fall term (or summer continuing to fall) and having earned an AA degree from an institution in the Florida College System. (1) Cohorts are based on undergraduate students who enter the institution in the Fall term (or Summer term and continue into the Fall term); (2) Success Rate measures the percentage of an initial cohort of students who have either graduated or are still enrolled; (3) since degrees can be awarded after the last semester of coursework, the most recent year of data in this table provides preliminary graduation rate data that may change with the addition of "late degrees". Late degrees reported in conjunction with the IPEDS Graduation Rate Survey due in mid-April will be reflected in the following year. 


\section{Section 4 - Undergraduate Education (continued)}

TABLE 4F. Other Transfer Progression and Graduation Rates

\begin{tabular}{cccccc}
$\mathbf{5}$ - Year Rates & $\mathbf{2 0 0 4 - 0 9}$ & $\mathbf{2 0 0 5 - 1 0}$ & $\mathbf{2 0 0 6 - 1 1}$ & $\mathbf{2 0 0 7 - 1 2}$ & $\begin{array}{c}\mathbf{2 0 0 8 - 1 3} \\
\text { Preliminary }\end{array}$ \\
\hline Cohort Size & 2026 & 2064 & 2,139 & 2,364 & 1,877
\end{tabular}

From Same University

$\begin{array}{lccccc}\% \text { Graduated } & 53 \% & 52 \% & 58 \% & 57 \% & 64 \% \\ \% \text { Still Enrolled } & 7 \% & 7 \% & 7 \% & 6 \% & 6 \%\end{array}$

\section{From Other SUS University}

$\begin{array}{lccccc}\% \text { Graduated } & 3 \% & 3 \% & 4 \% & 3 \% & 2 \% \\ \% \text { Still Enrolled } & 1 \% & 1 \% & 1 \% & 1 \% & 1 \%\end{array}$

\section{From State University System}

$\begin{array}{lccccc}\text { \% Graduated } & 56 \% & 55 \% & 62 \% & 61 \% & 66 \% \\ \% \text { Still Enrolled } & 8 \% & 8 \% & 8 \% & 8 \% & 6 \% \\ \% \text { Success Rate } & 64 \% & 62 \% & 70 \% & 68 \% & 73 \%\end{array}$

Notes: (1) Cohorts are based on undergraduate students who enter the institution in the Fall term (or Summer term and continue into the Fall term); (2) Success Rate measures the percentage of an initial cohort of students who have either graduated or are still enrolled; (3) since degrees can be awarded after the last semester of coursework, the most recent year of data in this table provides preliminary graduation rate data that may change with the addition of "late degrees". Late degrees reported in conjunction with the IPEDS Graduation Rate Survey due in mid-April will be reflected in the following year. 


\section{Section 4 - Undergraduate Education (continued)} TABLE 4G. Baccalaureate Degrees Awarded

$\begin{array}{lccccc} & \mathbf{2 0 0 8 - 0 9} & \mathbf{2 0 0 9 - 1 0} & \mathbf{2 0 1 0 - 1 1} & \mathbf{2 0 1 1 - 1 2} & \mathbf{2 0 1 2 - 1 3} \\ \text { Degree Count } & 6,140 & 6,723 & 6,845 & 7,780 & 7,617\end{array}$

Note: Table 4G represents the counts of distinct baccalaureate degrees. In those cases where baccalaureate degrees are awarded under two different degree CIPs, a distinction is made between "dual degrees" and "dual majors." Dual degrees are counted as separate degrees (i.e., counted twice), and include those cases where the second major differs substantially from the first because either the college is different, the degree designation is different (e.g., BA, BS, BBA, BFA, etc.), or the degree CIP is in a different 2-digit range (e.g., 51* vs. 52*); in these cases, the second degree CIP receives a "degree fraction" of 1.0. If these conditions do not apply, the second major is considered a dual major, and the degree associated with it is not counted a second time; in these cases, each dual major degree CIP receives a degree fraction of .5 apiece. The calculation of degree fractions is made according to each institution's criteria. In those rare cases where there are three or more awarded baccalaureate degree CIPs, analogous logic is extended to cover the additional degree CIPs and their corresponding degree fractions.

\section{TABLE 4H. Baccalaureate Degrees Awarded in Programs of Strategic Emphasis}

\begin{tabular}{|c|c|c|c|c|c|}
\hline & 2008-09 & $2009-10$ & $2010-11$ & 2011-12 & 2012-13 \\
\hline $\begin{array}{l}\text { Science, Technology, } \\
\text { Engineering, and Math }\end{array}$ & 1,323 & 1,472 & 1,554 & 1,844 & 1,987 \\
\hline $\begin{array}{l}\text { Health Professions } \\
\text { *only disciplines in critical need }\end{array}$ & 414 & 432 & 439 & 683 & 803 \\
\hline $\begin{array}{l}\text { Security and Emergency } \\
\text { Services }\end{array}$ & 321 & 356 & 383 & 394 & 435 \\
\hline Globalization & 432 & 454 & 490 & 560 & 500 \\
\hline $\begin{array}{l}\text { Education } \\
\text { *only disciplines in critical need }\end{array}$ & 85 & 91 & 109 & 132 & 112 \\
\hline SUBTOTAL & 2,575 & 2,805 & 2,975 & 3,613 & 3,837 \\
\hline $\begin{array}{l}\text { Percentage of All Baccalaureate } \\
\text { Degrees (includes second majors) }\end{array}$ & $42 \%$ & $42 \%$ & $43 \%$ & $46 \%$ & $49 \%$ \\
\hline
\end{tabular}

Notes: This is a count of baccalaureate majors for specific Programs of Strategic Emphasis, as determined by the Board of Governors staff with consultation with business and industry groups and input from universities. A student who has multiple majors in the subset of targeted Classification of Instruction Program codes will be counted twice (i.e., double-majors are included). ${ }^{*}$ This data represents select disciplines within these five areas and does not reflect all degrees awarded within the general field (of education or health). The Board of Governors will review Board staff recommendations to update this list at their November 2013 meeting. Any changes from that meeting will be incorporated into subsequent Accountability Reports.

Note: The denominator used in the percentage includes second majors that are not reported in the degree count in table 4G. 


\section{Section 4 - Undergraduate Education (continued)}

TABLE 4I. Baccalaureate Degrees Awarded to Underrepresented Groups

2008-09 2009-10 2010-11 2011-12 2012-13

\section{Non-Hispanic Black}

$\begin{array}{cccccc}\text { Number of Degrees } & 786 & 795 & 845 & 881 & 884 \\ \text { Percentage of Degrees } & 14 \% & 13 \% & 13 \% & 11 \% & 12 \%\end{array}$

Hispanic

$\begin{array}{cccccc}\text { Number of Degrees } & 759 & 830 & 1,013 & 1,312 & 1,285 \\ \text { Percentage of Degrees } & 13 \% & 13 \% & 16 \% & 17 \% & 17 \%\end{array}$

Pell-Grant Recipients

$\begin{array}{cccccc}\text { Number of Degrees } & 2,578 & 2,806 & 3,130 & 3,859 & 4,039 \\ \text { Percentage of Degrees } & 43 \% & 42 \% & 46 \% & 50 \% & 54 \%\end{array}$

Note: Non-Hispanic Black and Hispanic do not include students classified as Non-Resident Alien or students with a missing race code. Students who earn two distinct degrees in the same term are counted twice - whether their degrees are from the same six-digit CIP code or different CIP codes. Students who earn only one degree are counted once - even if they completed multiple majors or tracks. Percentage of Degrees is based on the number of baccalaureate degrees awarded to non-Hispanic Black and Hispanic students divided by the total degrees awarded - excluding those awarded to nonresident aliens and unreported.

Pell-Grant recipients are defined as those students who have received a Pell grant from any SUS Institution within six years of graduation - excluding those awarded to non-resident aliens, who are only eligible for Pell grants in special circumstances. Percentage of Degrees is based on the number of baccalaureate degrees awarded to Pell recipients, as shown above, divided by the total degrees awarded - excluding those awarded to non-resident aliens.

Notes on Trends: In 2007, the US Department of Education re-classified the taxonomy for self-reported race/ethnicity categories and allowed universities a two-year phase-in process before all institutions were required to report based on the new categories for the 2010-11 academic year. This reclassification will impact trends. 


\section{Section 4 - Undergraduate Education (continued) TABLE 4J. Baccalaureate Degrees Without Excess Credit Hours}

\begin{tabular}{lccccc} 
& $\mathbf{2 0 0 8 - 0 9}$ & $\mathbf{2 0 0 9 - 1 0}$ & $\mathbf{2 0 1 0 - 1 1}$ & $\mathbf{2 0 1 1 - 1 2}$ & $\mathbf{2 0 1 2 - 1 3}$ \\
\hline FTIC &. &. &. & $56 \%$ & $51 \%$ \\
\hline AA Transfers &. &. &. & $58 \%$ & $63 \%$ \\
\hline Other Transfers &. &. &. & $39 \%$ & $46 \%$ \\
\hline TOTAL &. &. &. & $\mathbf{5 2 \%}$ & $\mathbf{5 3 \%}$
\end{tabular}

Notes: This table is based on statute 1009.286 (see link), and excludes certain types of student credits (ie, accelerated mechanisms, remedial coursework, non-native credit hours that are not used toward the degree, non-native credit hours from failed, incomplete, withdrawn, or repeated courses, credit hours from internship programs, credit hours up to 10 foreign language credit hours for transfer students in Florida, and credit hours earned in military science courses that are part of the Reserve Officers' Training Corps (ROTC) program). This metric is not the same as the Excess Hours Surcharge, which has multiple cohorts with varying fee rates. This table reports the percentage of baccalaureate degrees awarded within $110 \%$ of the catalog hours required for a degree based on the Board of Governors Academic Program Inventory. This calculation is based on Hours To Degree data submitted by universities to the Board of Governors and excludes recent graduates who have already earned a baccalaureate degree.

Note*: Improvements were made to data collection process beginning with 2012-13 data.

\section{TABLE 4K. Undergraduate Course Offerings}

Fall 2008 Fall 2009 Fall 2010 Fall 2011* ${ }^{\star}$ Fall 2012*

$\begin{array}{llllll}\text { Number of } & 2,453 & 2,591 & 3,087 & 2,830 & 2,772 \\ \text { Course Sections } & 2,401\end{array}$

\section{Percentage of Undergraduate Course Sections by Class Size}

\begin{tabular}{lccccc}
\hline Fewer than 30 Students & $55 \%$ & $58 \%$ & $62 \%$ & $62 \%$ & $62 \%$ \\
\hline 30 to 49 Students & $28 \%$ & $27 \%$ & $24 \%$ & $24 \%$ & $24 \%$ \\
\hline 50 to 99 Students & $13 \%$ & $12 \%$ & $10 \%$ & $10 \%$ & $10 \%$ \\
\hline 100 or More Students & $4 \%$ & $4 \%$ & $4 \%$ & $3 \%$ & $4 \%$
\end{tabular}

Notes: This data is based on Common Data Set (CDS) definitions. According to CDS, a "class section is an organized course offered for credit, identified by discipline and number, meeting at a stated time or times in a classroom or similar setting, and not a subsection such as a laboratory or discussion session. Undergraduate class sections are defined as any sections in which at least one degree-seeking undergraduate student is enrolled for credit. Exclude distance learning classes and noncredit classes and individual instruction such as dissertation or thesis research, music instruction, or one-to-one readings. Exclude students in independent study, co-operative programs, internships, foreign language taped tutor sessions, practicums, and all students in one-on-one classes. 


\section{Section 4 - Undergraduate Education (continued)}

TABLE 4L. Percentage of Undergraduate Credit Hours Taught by Instructor Type

\begin{tabular}{lccccc} 
& $\mathbf{2 0 0 8 - 0 9}$ & $\mathbf{2 0 0 9 - 1 0}$ & $\mathbf{2 0 1 0 - 1 1}$ & $\mathbf{2 0 1 1 - 1 2}$ & $\mathbf{2 0 1 2 - 1 3}$ \\
\hline Faculty & $63 \%$ & $65 \%$ & $66 \%$ & $68 \%$ & $66 \%$ \\
\hline Adjunct Faculty & $20 \%$ & $18 \%$ & $16 \%$ & $13 \%$ & $16 \%$ \\
\hline Graduate Students & $16 \%$ & $16 \%$ & $17 \%$ & $18 \%$ & $17 \%$ \\
\hline Other Instructors & $1 \%$ & $1 \%$ & $2 \%$ & $1 \%$ & $1 \%$
\end{tabular}

Note: The total number of undergraduate state fundable credit hours taught will be divided by the undergraduate credit hours taught by each instructor type to create a distribution of the percentage taught by each instructor type. Four instructor types are defined as faculty (pay plans 01, 02, and 22), OPS faculty (pay plan 06), graduate student instructors (pay plan 05), and others (all other pay plans). If a course has more than one instructor, then the university's reported allocation of section effort will determine the allocation of the course's total credit hours to each instructor. The definition of faculty varies for Tables 4L, 4M and 4N. For Faculty Teaching Undergraduates, the definition of faculty is based on pay plans 01, 02, and 22.

\section{TABLE 4M. Student/Faculty Ratio}

Fall 2008 Fall $2009 \quad$ Fall $2010 \quad$ Fall $2011 \quad$ Fall 2012

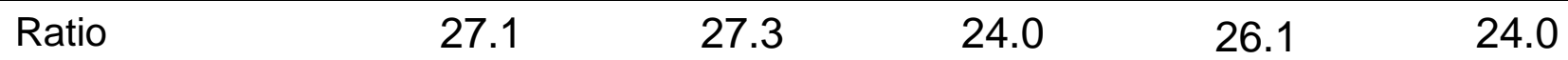

Note: This data is based on Common Data Set (CDS) definitions. This is the Fall ratio of full-time equivalent students (full-time plus $1 / 3$ part time) to fulltime equivalent instructional faculty (full time plus $1 / 3$ part time). In the ratio calculations, exclude both faculty and students in stand-alone graduate or professional programs such as medicine, law, veterinary, dentistry, social work, business, or public health in which faculty teach virtually only graduatelevel students. Do not count undergraduate or graduate student teaching assistants as faculty.

\section{TABLE 4N. Professional Licensure/Certification Exams for Undergraduates}

\begin{tabular}{lccccc} 
Nursing: National Council Licensure & Examination for Registered Nurses & \\
& $\mathbf{2 0 0 8}$ & $\mathbf{2 0 0 9}$ & $\mathbf{2 0 1 0}$ & $\mathbf{2 0 1 1}$ & $\mathbf{2 0 1 2}$ \\
\hline Examinees & 157 & 151 & 169 & 210 & 129 \\
First-time Pass Rate & $98 \%$ & $96 \%$ & $96 \%$ & $95 \%$ & $93 \%$ \\
National Benchmark & $88 \%$ & $90 \%$ & $89 \%$ & $89 \%$ & $92 \%$
\end{tabular}

Note: Pass rate for first-time examinees for the National Council Licensure Examination for Registered Nurses (NCLEX-RN) are based on the performance of graduates of baccalaureate nursing programs. National benchmark data is based on Jan-Dec NCLEX-RN results for first-time examinees from students in US-educated baccalaureate degree programs as published by the National Council of State Boards of Nursing. 


\section{Section 5 - Graduate Education}

\section{TABLE 5A. Graduate Degree Program Changes in AY 2012-13}

\begin{tabular}{|c|c|c|c|c|c|c|}
\hline Title of Program & $\begin{array}{l}\text { Six-digit } \\
\text { CIP } \\
\text { Code }\end{array}$ & $\begin{array}{l}\text { Degree } \\
\text { Level }\end{array}$ & $\begin{array}{l}\text { Date of } \\
\text { UBOT } \\
\text { Action }\end{array}$ & $\begin{array}{l}\text { Starting } \\
\text { or Ending } \\
\text { Term }\end{array}$ & $\begin{array}{l}\text { Date of } \\
\text { Board of } \\
\text { Governors } \\
\text { Action }\end{array}$ & Comments \\
\hline \multicolumn{7}{|l|}{ New Programs } \\
\hline Physician Assistant & 51.0912 & M & $3 / 21 / 2013$ & Summer 2015 & & Tampa \\
\hline $\begin{array}{l}\text { Sport and Entertainment } \\
\text { Management }\end{array}$ & 31.0504 & M & $3 / 21 / 2013$ & Fall 2013 & & Tampa \\
\hline Applied Behavior Analysis & 42.2814 & $\mathrm{R}$ & $12 / 8 / 2012$ & Fall 2013 & $6 / 21 / 2012$ & Tampa \\
\hline \multicolumn{7}{|l|}{ Terminated Programs } \\
\hline \multicolumn{7}{|l|}{ None } \\
\hline \multicolumn{7}{|l|}{ Inactive Programs } \\
\hline \multicolumn{7}{|l|}{ None } \\
\hline \multicolumn{7}{|c|}{ New Programs Considered By University But Not Approved } \\
\hline \multicolumn{7}{|c|}{ None } \\
\hline
\end{tabular}

Note: This table does not include new majors or concentrations added under an existing degree program CIP Code. This table reports the new and terminated program changes based on Board action dates between May 5, 2012 and May 4, 2013.

New Programs are proposed new degree programs that have been completely through the approval process at the university and, if appropriate, the Board of Governors. Does not include new majors or concentrations added under an existing degree program CIP Code.

Terminated Programs are degree programs for which the entire CIP Code has been terminated and removed from the university's inventory of degree programs. Does not include majors or concentrations terminated under an existing degree program CIP Code if the code is to remain active on the academic degree inventory.

Inactive Programs are degree programs for which enrollments have been temporarily suspended for the entire CIP Code, but the program CIP Code has not been terminated. Does not include majors or concentrations suspended under an existing degree program CIP Code if the code is to remain active on the academic degree inventory and new enrollments in any active major will be reported.

New Programs Considered by University But Not Approved includes any programs considered by the university board of trustees, or any committee of the board, but not approved for implementation. Also include any programs that were returned prior to board consideration by the university administration for additional development, significant revisions, or re-conceptualization; regardless of whether the proposal was eventually taken to the university board for approval. Count the returns once per program, not multiple times the proposal was returned for revisions, unless there is a total re-conceptualization that brings forward a substantially different program in a different CIP Code. 
Section 5 - Graduate Education (continued)

TABLE 5B. Graduate Degrees Awarded

\begin{tabular}{lccccc} 
& $\mathbf{2 0 0 8 - 0 9}$ & $\mathbf{2 0 0 9 - 1 0}$ & $\mathbf{2 0 1 0 - 1 1}$ & $\mathbf{2 0 1 1 - 1 2}$ & $\mathbf{2 0 1 2 - 1 3}$ \\
\hline \multicolumn{1}{c}{ TOTAL } & 2,097 & 2,259 & 2,293 & 2,524 & 2,558 \\
\hline Masters and Specialist & 248 & 244 & 269 & 271 & 295 \\
\hline Research Doctoral & 154 & 156 & 156 & 146 & 153 \\
\hline Professional Doctoral & 114 & 116 & 109 & 112 & 106 \\
\hline a) Medicine & 0 & 0 & 0 & 0 & 0 \\
b) Law & 0 & 0 & 0 & 0 & 0 \\
c) Pharmacy & $\mathbf{2 , 4 9 9}$ & $\mathbf{2 , 6 5 9}$ & $\mathbf{2 , 7 1 8}$ & $\mathbf{2 , 9 4 1}$ & $\mathbf{3 , 0 0 6}$
\end{tabular}

Note: The total number of Professional Doctoral degrees includes other programs that are not specifically identified in lines $a, b$, and $c$.

\section{TABLE 5C. Graduate Degrees Awarded in Areas of Strategic Emphasis}

2008-09 2009-10 2010-11 2011-12 2012-13

\begin{tabular}{|c|c|c|c|c|c|}
\hline $\begin{array}{l}\text { Science, Technology, } \\
\text { Engineering, and Math }\end{array}$ & 528 & 614 & 648 & 724 & 837 \\
\hline $\begin{array}{l}\text { Health Professions } \\
\text { *only disciplines in critical need }\end{array}$ & 497 & 562 & 662 & 650 & 697 \\
\hline $\begin{array}{l}\text { Security and Emergency } \\
\text { Services }\end{array}$ & 50 & 36 & 29 & 38 & 37 \\
\hline Globalization & 41 & 53 & 49 & 67 & 79 \\
\hline $\begin{array}{l}\text { Education } \\
\text { *only disciplines in critical need }\end{array}$ & 138 & 129 & 108 & 135 & 110 \\
\hline SUBTOTAL & 1,254 & 1,394 & 1,496 & 1,614 & 1,760 \\
\hline $\begin{array}{l}\text { Percent of All } \\
\text { Graduate Degrees }\end{array}$ & $50 \%$ & $52 \%$ & $54 \%$ & $55 \%$ & $59 \%$ \\
\hline
\end{tabular}




\section{Section 5 - Graduate Education (continued)}

\section{TABLE 5D. Professional Licensure Exams for Graduate Programs}

Medicine: US Medical Licensing Exam - Step 1 (for 2nd year MD students)

\begin{tabular}{lccccc} 
& $\mathbf{2 0 0 9}$ & $\mathbf{2 0 1 0}$ & $\mathbf{2 0 1 1}$ & $\mathbf{2 0 1 2}$ & $\mathbf{2 0 1 3}$ \\
\hline Examinees & 117 & 116 & 110 & 125 & Preliminary \\
First-time Pass Rate & $97 \%$ & $97 \%$ & $99 \%$ & $91 \%$ & $96 \%$ \\
National Benchmark & $91 \%$ & $94 \%$ & $96 \%$ & $96 \%$ & $96 \%$
\end{tabular}

Medicine: US Medical Licensing Exam - Step 2 Clinical Knowledge (for $4^{\text {th }}$ year MD students)

\begin{tabular}{lccccc} 
& $\mathbf{2 0 0 8 - 0 9}$ & $\mathbf{2 0 0 9 - 1 0}$ & $\mathbf{2 0 1 0 - 1 1}$ & $\mathbf{2 0 1 1 - 1 2}$ & $\mathbf{2 0 1 2 - 1 3}$ \\
\hline Examinees & 121 & 128 & 122 & 115 & 152 \\
First-time Pass Rate & $100 \%$ & $100 \%$ & $99 \%$ & $99 \%$ & $100 \%$ \\
National Benchmark & $96 \%$ & $97 \%$ & $97 \%$ & $98 \%$ & $98 \%$
\end{tabular}

Medicine: US Medical Licensing Exam - Step 2 Clinical Skills (for $4^{\text {th }}$ year MD students)

\begin{tabular}{lccccc} 
& $\mathbf{2 0 0 8 - 0 9}$ & $\mathbf{2 0 0 9 - 1 0}$ & $\mathbf{2 0 1 0 - 1 1}$ & $\mathbf{2 0 1 1 - 1 2}$ & $\mathbf{2 0 1 2 - 1 3}$ \\
\hline Examinees & 118 & 116 & 122 & 100 & 128 \\
First-time Pass Rate & $97 \%$ & $96 \%$ & $100 \%$ & $98 \%$ & $99 \%$ \\
National Benchmark & $97 \%$ & $97 \%$ & $98 \%$ & $97 \%$ & $98 \%$
\end{tabular}

Physical Therapy: National Physical Therapy Examinations

\begin{tabular}{lccccc} 
& 2006-08* $^{*}$ & 2007-09*$^{*}$ & 2008-10 & $\mathbf{2 0 0 9 - 1 1}$ & $\mathbf{2 0 1 0 - 1 2}$ \\
\hline Examinees & 43 & 51 & 81 & 96 & 93 \\
First-time Pass Rate & $88 \%$ & $86 \%$ & $85 \%$ & $87 \%$ & $90 \%$ \\
National Benchmark & $86 \%$ & $87 \%$ & $87 \%$ & $89 \%$ & $89 \%$
\end{tabular}

*No USF Graduates in 2007 


\section{Section 6 - Research and Economic Development}

TABLE 6A. Research and Development

\section{$2007-08 \quad 2008-09 \quad 2009-10 \quad 2010-11 \quad 2011-12$

\section{R\&D Expenditures}

Total (S\&E and non-S\&E)

(\$1,000s)

Federally Funded

(\$1,000s)

Percent Funded

From External Sources

Total R\&D Expenditures

Per Full-Time, Tenured,

Tenure-Earning Faculty

Member (\$)

\section{Technology Transfer}

Invention Disclosures

U.S. Patents Issued

Patents Issued Per 1,000

Full-Time, Tenured and

Tenure-Earning Faculty

Licenses/ Options Executed
Campus R\&D data
is not available
for these
historical years.

\begin{tabular}{ccc}
$\$ 385,029$ & $\$ 394,963$ & $\$ 443,206$ \\
\hline 243,017 & $\$ 243,030$ & $\$ 236,148$ \\
$79 \%$ & $78 \%$ & $68 \%$
\end{tabular}

$\$ 363,921 \quad \$ 394,963$

$\$ 433,665$

\section{Licensing Income}

Received (\$)

Number of Start-Up

Companies
139

141

172

161

36

66

91

80

83

$\begin{array}{lllll}26 & 28 & 52 & 80 & 83\end{array}$

25

37

36

52

Note: R\&D Expenditures are based on the National Science Foundation's annual Survey of R\&D Expenditures at Universities and Colleges (data include Science \& Engineering and non-Science \& Engineering awards). Percent Funded from External Sources is defined as funds from federal, private industry and other sources (non-state and non-institutional funds). Total R\&D expenditures are divided by fall, full-time tenured/tenure-track faculty as reported to IPEDS (FGCU includes both tenured/tenure-track and non-tenure/track faculty). The fall faculty year used will align with the beginning of the fiscal year, so that (e.g.) 2007 FY R\&D expenditures are divided by fall 2006 faculty. Technology Transfer data are based on the Association of University Technology Managers Annual Licensing Survey. Licensing Income Received refers to license issue fees, payments under options, annual minimums, running royalties, termination payments, amount of equity received when cashed-in, and software and biological material end-user license fees of $\$ 1,000$ or more, but not research funding, patent expense reimbursement, valuation of equity not cashed-in, software and biological material end-user license fees of less than $\$ 1,000$, or trademark licensing royalties from university insignia. Number of Start-up Companies that were dependent upon the licensing of University technology for initiation. 


\section{Section 6 - Research and Economic Development (continued)}

\section{TABLE 6B. Centers of Excellence}

Name of Center:

Year Created:
CENTER FOR DRUG DISCOVERY AND INNOVATION

FY 2007
Cumulative

(since inception

to June 2013)
Fiscal Year

2012-13

\section{Research Effectiveness}

Only includes data for activities directly associated with the Center. Does not include the non-Center activities for faculty who are associated with the Center.

Number of Competitive Grants Applied For

Value of Competitive Grants Applied For (\$)

Number of Competitive Grants Received

Value of Competitive Grants Received (\$)

Total Research Expenditures (\$)

Number of Publications in Refereed Journals

From Center Research

Number of Invention Disclosures

Number of Licenses/Options Executed

Licensing Income Received (\$)

\begin{tabular}{|c|c|}
\hline 160 & 27 \\
\hline$\$ 111,119,864$ & $\$ 36,950,210$ \\
\hline 57 & 14 \\
\hline$\$ 28,428,541$ & $\$ 11,159,368$ \\
\hline$\$ 18,156,103$ & $\$ 2,703,320$ \\
\hline 172 & 25 \\
\hline 42 & 14 \\
\hline 3 & 1 \\
\hline$\$ 163,071$ & $\$ 0$ \\
\hline
\end{tabular}

\section{Collaboration Effectiveness}

Only reports on relationships that include financial or in-kind support.

Collaborations with Other Postsecondary Institutions

Collaborations with Private Industry

Collaborations with K-12 Education Systems/Schools

Undergraduate and Graduate Students Supported

with Center Funds

\section{Economic Development Effectiveness}

Number of Start-Up companies

with a physical presence, or employees, in Florida

Jobs Created By Start-Up Companies

Associated with the Center

Specialized Industry Training and Education

Private-sector Resources Used to Support

the Center's Operations

Narrative Comments on next page. 


\section{Section 6 - Research and Economic Development (continued) TABLE 6B. Centers of Excellence (continued)}

\section{Name of Center} CENTER FOR DRUG DISCOVERY AND INNOVATION

\section{Narrative Comments [Most Recent Year]:}

(1) On August 7, 2013, Dr. James Leahy, Medicinal Chemist, was appointed as a faculty member with the center through a joint appointment with the Chemistry Department and the Center for Drug Discovery and Innovation. (2) On September 24, 2012, Dr. Ziming Zhang was appointed as the manager for the center's NMR Core Facility. On November 8, 2012, CDDI had its opening reception in the Galleria of the IDR Building. The event had over 150 people in attendance and this included deans from both USF Tampa and USF St.

Petersburg, and faculty and graduate students from departments across USF. Also in attendance were representatives from companies within the USF Tampa Bay Technology Incubator as well as investigators from both the private and public sectors. (4) In February 2013, CDDI's core facility managers started to provide training workshops to both members of academia and industry that are users of the center's facilities. This informative training provides the core managers the opportunity to illustrate techniques and methodology unique to their labs. These sessions also afford the participants the opportunity for hands-on experience using specialized equipment not normally found in most research labs. (5) On March 29, 2013, CDDI along with Global Health hosted the Frontiers of Drug Discovery Symposium. This conference provided pre-doctoral students and program faculty the opportunity to present their infectious disease research as it relates to academic drug discovery. Guest speakers included one of NIH'S leading researchers in Malaria and Vector Research, Dr. Thomas Wellems. 